UNIVERSIDADE DE BRASÍLIA

INSTITUTO DE RELAÇÕES INTERNACIONAIS

X CURSO DE ESPECIALIZAÇÃO EM RELAÇÕES INTERNACIONAIS

\title{
A TRANSIÇÃO DE DENG XIAOPING E A CHINA CONTEMPORÂNEA: CONTINUIDADE E APROFUNDAMENTO DAS REFORMAS NA ERA GLOBALIZADA.
}

BRUNO MACÊDO MENDONÇA

Trabalho de Conclusão de Curso de
Relações Internacionais para a
Universidade de Brasília - UnB,
apresentado como requisito parcial à
obtenção do título de Especialista em
Relações Internacionais.

- Brasília, 2009 - 
BRUNO MACÊDO MENDONÇA

\section{A TRANSIÇÃO DE DENG XIAOPING E A CHINA CONTEMPORÂNEA: CONTINUIDADE E APROFUNDAMENTO DAS REFORMAS NA ERA GLOBALIZADA.}

Trabalho de Conclusão de Curso de Relações Internacionais para a Universidade de Brasília - UnB, apresentado como requisito parcial à obtenção do título de Especialista em Relações Internacionais.

Orientador: Prof. Eiiti Sato. 
FICHA CATALOGRÁFICA

MENDONÇA, Bruno M.

A transição de Deng Xiaoping e a China contemporânea: continuidade e aprofundamento das reformas na era globalizada. / Bruno Macêdo Mendonça; Orientador: Eiiti Sato. - Brasília, 2009.

$71 \mathrm{p}$.

Trabalho de Conclusão de Curso. Instituto de Relações Internacionais - Universidade de Brasília. Curso de Especialização em Relações Internacionais.

1. Política Externa Chinesa. 2. Abertura econômica da China. 3. Relações internacionais da China.

Instituto de Relações Internacionais. 
O homem superior entende o que é certo; o inferior percebe o que é lucrativo. CONFÚCIO

Enriquecer é glorioso. DENG XIAOPING 


\section{RESUMO}

O objetivo deste trabalho é analisar o período de reformas chinês, liderado por Deng Xiaoping ao final dos anos setenta, traçando uma comparação com o momento atual e apontando seus traços de continuidade ou de ruptura. A ênfase recai sobre o papel do

Estado e de seus líderes no processo e os aspectos que envolvem a Política Externa Chinesa. 


\begin{abstract}
The aim of this paper is to analyze the Chinese period of reforms led by Deng Xiaoping at the end of the 1970's by making a comparison with the present moment and pointing out its trends towards continuity or rupture. The emphasis is placed on the role of the State and its leaders in the process and the aspects which involve the Chinese Foreign Policy.
\end{abstract}




\section{SUMÁRIO}

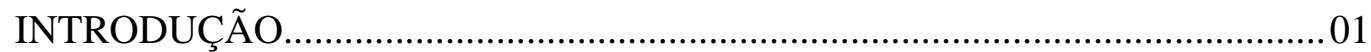

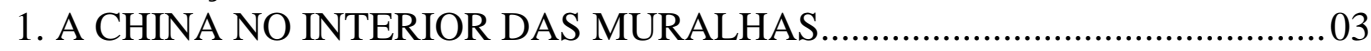

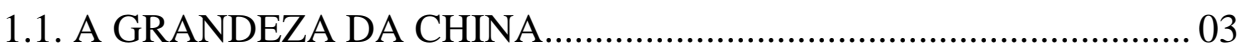

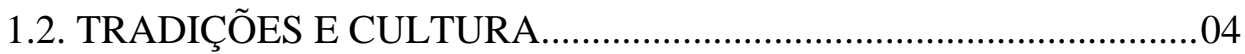

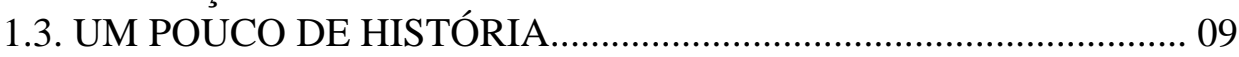

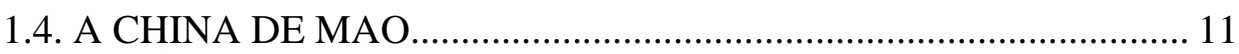

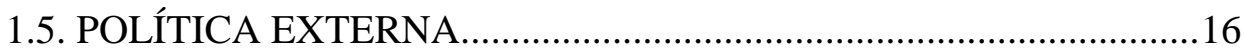

2. FISSURAS NO MURO: A TRANSIÇÃO DE DENG XIAOPING...................... 19

2.1. O PAPEL DA LIDERANÇA NA CHINA............................................ 19

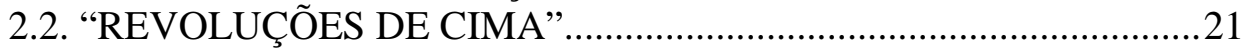

2.3. REVOLUCIONANDO O PENSAMENTO_.................................... 24

2.4. REVOLUÇÃO NA PRÁTICA.........................................................2 27

2.5. POLÍTICA EXTERNA.............................................................................33

3. O DRAGÃO LIBERTO: A CHINA ALÉM DOS MUROS................................... 36

3.1. DADOS SOBRE A CHINA CONTEMPORÂNEA............................ 36

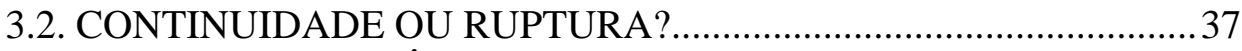

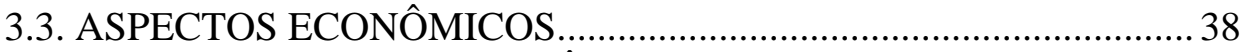

3.3.1. ARRANJOS ECONÔMICOS MULTILATERAIS................38

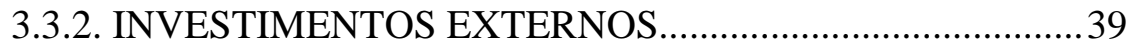

3.3.3. INGRESSO NA OMC .......................................................... 41

3.3.4. ACORDOS DE LIVRE COMÉRCIO................................... 42

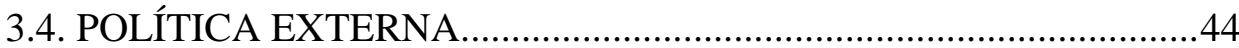

3.4.1. UMA NOVA VISÃO DE MUNDO?...................................... 44

3.4.2. CONQUISTANDO A VIZINHANÇA....................................48

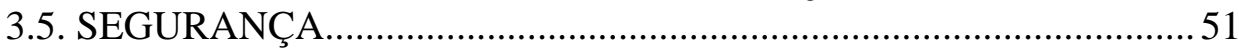

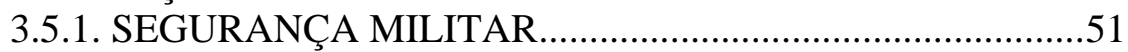

3.5.2. SEGURANÇA ENERGÉTICA............................................. 56

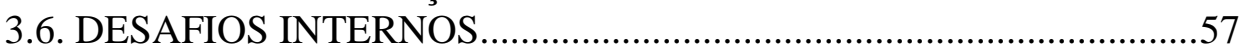

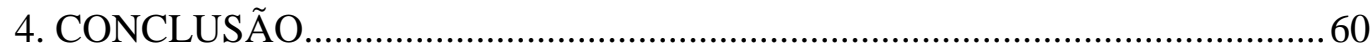

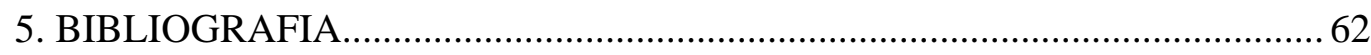




\section{INTRODUÇÃO}

Este trabalho analisa o período de reformas chinês inaugurado pelo líder Deng Xiaoping após a morte de Mao Tsé-tung, ao final dos anos setenta, e suas repercussões, sobretudo em termos de política externa, sobre a China contemporânea. Objetiva apontar os traços de continuidade das políticas atuais em relação ao período de transição, desenvolvendo alguns temas de política externa e enfatizando o aprofundamento do modelo.

O estudo é relevante em razão da ascensão chinesa no cenário internacional, que provoca indagações sobre suas intenções e seu modelo de inserção internacional. Nesse sentido, cumpre-nos tentar desvendar este modelo, não só porque a sociedade internacional será por ele afetada, mas também porque em grande medida produziu um sucesso econômico nada desprezível nos últimos vinte anos. Analisamos o período inicial das reformas e, ao final, o momento atual, traçando o paralelo entre um e outro para enfatizar os traços de continuidade que os conectam.

Nosso argumento se embasa num determinado método de enxergar a história chinesa, como constituída de “ciclos” de “abertura” e “fechamento” para o mundo, tal como o descreve Magnoli (2004):

Ao longo dos séculos, a China experimentou o ritmo dos ciclos pendulares de abertura e fechamento em relação ao mundo exterior. Os períodos de abertura corresponderam à hegemonia do comércio, dos comerciantes e dos portos; os de isolamento, à hegemonia das elites político-militares e do poder territorializado. O conflito entre essas tendências refletiu a disputa entre as dinastias e a burocracia confuciana de Pequim, de um lado, e os empreendedores dos portos do Leste e Sudeste, de outro.

Utilizando este paradigma, defendemos que o fim da era maoísta corresponde ao fim de um longo ciclo de fechamento, a partir do qual se transita para uma abertura gradual da economia chinesa. Nesse sentido, nossa tese é a de que o momento atual corresponde a um aprofundamento desta transição, configurando-se num claro período de continuidade dentro do ciclo de abertura. 
A bibliografia utilizada é composta, na sua maioria, por artigos de revistas especializadas em política externa, sobretudo de língua inglesa - o tema não parece ter sido muito abordado em trabalhos de língua portuguesa. Alguns livros tratando de história chinesa também foram consultados. O trabalho foi dividido em três capítulos.

No primeiro, estudamos alguns traços da cultura chinesa como uma forma de nos aproximar da mentalidade deste povo para, em seguida, tratarmos dos acontecimentos que configuram o período maoísta. No segundo capítulo estudamos o período de transição de Deng Xiaoping, com as transformações a ele inerentes. No terceiro capítulo, finalmente, analisamos os traços que demonstram o aprofundamento das políticas da "era da transição", numa clara linha de continuidade às reformas. $\mathrm{Na}$ conclusão, teceremos algumas considerações sobre os resultados do trabalho. 


\section{A CHINA NO INTERIOR DAS MURALHAS}

A civilização chinesa é uma das mais antigas e complexas do mundo. Por esta razão, estudos sobre ela são exercícios intelectuais delicados, ainda mais quando se pretende analisar aspectos de sua cultura e de sua tradição. Neste primeiro capítulo, não obstante, a pretensão é de, em primeiro lugar, trazer à tona algumas visões acerca desses aspectos que servem para embasar o argumento de nossa tese e, em segundo lugar, baseando-nos no método descrito na introdução, descrever sumariamente o término de um longo período de “fechamento" na história chinesa.

\subsection{A Grandeza da China}

A China é não só uma das mais antigas, mas foi durante muito tempo a maior civilização do mundo, tendo inclusive, segundo alguns autores, superado Roma (FAIRBANK, 2008). Este mesmo autor argumenta que ao final do século XVIII, a China terminava um longo processo de civilização que começara há oito séculos atrás, com a dinastia Song (2008, p. 160).

O período Song, que termina no século XIV, foi de intensa atividade e criatividade $^{1}$. Sob essa dinastia é que a China produziu suas grandes invenções: “seda, porcelana, comportas de canal, escape de relógio, cadaste de leme, imprensa, pólvora” e muitas outras (FAIRBANK, 2008, p. 167)². Avançara também em muitos aspectos políticos, filosóficos e de governo; em técnicas de produção, como a do aço; em comércio exterior, por vias navegáveis. Sobre este último ponto, Fairbank (2008) afirma:

[...] o comércio exterior fornecia a maior parte da receita do governo. [...] Embarcações chinesas desciam pela costa da Ásia Oriental até as Índias e, dobrando a Índia, chegavam até mesmo à África Oriental. [...] A tecnologia

\footnotetext{
$1 \quad$ Nas palavras de Fairbank (2008, p. 128): “As mudanças na era dos Song foram tão amplas e tão espetaculares que um historiador japonês (Naitô Konan) viu nelas o berço da China moderna”. E continua: "Essa era moderna caracterizou-se pela importância decrescente que o governo assumiu para a vasta maioria do povo chinês, acompanhada por uma maior importância dada à cultura”.

2 Para uma lista de outras invenções do mesmo período, consulte-se David Landes (2003, pp. 55-59).
} 
náutica chinesa era a melhor do mundo nesse período. Os grandes navios compartimentados da China, dirigidos por um leme de popa e pelo uso de mapas e da bússola, podiam embarcar até quinhentos homens (p.99).

Estes e outros avanços não provocam divergências entre os sinólogos. Há consenso quanto aos aspectos que consubstanciaram a grandeza do império chinês e quanto a sua duração, que iria do início da dinastia Song, no século X, até meados da dinastia Ming (1368-1644). O que provoca debates até hoje inacabados são as razões do declínio chinês, com enfoque nos motivos de sua retirada voluntária de um cenário mundial em expansão.

Mas não tentaremos responder a tais indagações. Interessa-nos compreender alguns traços da cultura, dos valores e tradições da civilização chinesa e, seguindo o instrumental analítico acima descrito, apontar características do período de "fechamento" chinês que começaria na dinastia Ming e que só terminaria com a morte de Mao Tsé Tung nos anos setenta do século XX.

\subsection{Tradições e cultura}

Três traços da cultura chinesa chamam particularmente a atenção ao nos debruçarmos sobre sua história. São eles: 1) a preponderância do coletivo sobre o individual; 2) o culto à obediência e à hierarquia. e, talvez como conseqüência dos dois primeiros,3) a obediência ao Estado, seja este representado por um imperador que tira sua legitimidade do céu ou por um partido no poder.

Fairbank (2008, p. 35) tece comentários sobre como estas características começam na família, com a autoridade do pai sobre o filho, ou do mais velho sobre o mais jovem, ou do homem sobre a mulher, e se espraiam pelo Estado, gerando a obediência ao governante ${ }^{3}$. Estes sempre foram princípios fortes na sociedade chinesa e visavam à preservação da hierarquia nos relacionamentos, segundo parâmetros confucionistas. Conta-nos Fairbank sobre a dinastia Qing:

3 Citando Bluntschli, diz Fairbank (2008, p. 242): “as pessoas nascem para o Estado, não os Estados para as pessoas. Segundo esse ponto de vista baseado no Estado, que era usado pelos confucionistas como ponto de partida, todos os tipos de direito deveriam ser concedidos pelo Estado ou suspensos por ele quando de seu interesse”. 
A desobediência filial era o crime mais hediondo. Um filho que tivesse apenas batido em seus pais podia ser decapitado, enquanto um pai que batesse no filho até a morte caso fosse provocado pela desobediência dele mereceria apenas cem golpes de bambu pesado e poderia ser inteiramente perdoado. A mulher que batesse no marido mereceria cem golpes, mas o marido que batesse na mulher só era castigado se ela estivesse muito machucada e registrasse queixa $(2008,178)$.

Confúcio (551-479 a.C) foi talvez o pensador que mais influenciou a sociedade chinesa. O “código confuciano”, nessa linha de raciocínio, preza por princípios como o da manutenção da ordem, a possibilidade de aperfeiçoamento do indivíduo, a idéia de comportamentos adequados ao status de cada um, o enfoque na educação, a desaprovação do lucro ${ }^{4}$, entre outros. Trata-se de um código de conduta que, em simbiose com outras características da cultura geraram um povo que tem profundo respeito pela autoridade. Evidentemente, estamos a fazer generalizações, e nenhuma generalização é ideal. No entanto, não se deve desconsiderar esse que é um dos aspectos constantemente retratado pelos estudiosos, não só da China, como de grande parte dos povos orientais.

A maneira de encarar o lucro e, conseqüentemente, o comércio na China é outro ponto interessante e mereceria estudos aprofundados. Na sua história há períodos em que floresceu o poder marítimo chinês ${ }^{5}$, como demonstrado acima e uma das figuras mais conhecidas da epopéia marítima chinesa foi o grande eunuco Zheng He, que durante a dinastia Ming, entre os anos de 1405 e 1433 realizou suas famosas viagens, como nos conta Fairbank (2008, p.140):

A esquadra da primeira viagem, em 1405-1407, zarpou com cerca de 317 embarcações, das quais 62 eram navios do tesouro (a Armada Espanhola em 1588 possuía, no total, 132 embarcações). Zheng He foi acompanhado de setenta eunucos, 180 membros de pessoal médico, cinco astrólogos e

$4 \quad$ Diz-nos Landes (2003, p. 106): "O Estado confuciano abominava o sucesso mercantil”.

Hoje (2008), há estudos que procuram comprovar que os chineses é quem "descobriram” a América, como relatado pelo embaixador da China no Brasil, por ocasião do I Seminário Avançado em Relações Internacionais, por ele proferido na Universidade de Brasília em 25/09/2008 para um grupo restrito e presidido pela Dra. Ana Flávia Barros Platiau. 
trezentos oficiais, que comandavam uma força de 26.800 homens. Nas primeiras viagens visitaram a Índia e muitos portos no caminho. A quarta ultrapassou a Índia e foi até Hormuz. As três últimas viagens percorreram portos da costa oriental da África até o sul, em Malindi.

Apesar dos números impressionantes para a época, tais viagens não eram de exploração ou conquista e muito menos de comércio. Fez-se um pouco de comércio nelas, mas eram, sobretudo, diplomáticas. Cessaram em 1433 e segundo Fairbank (2008, p. 140) nunca mais se deu continuação a elas, tendo os seus registros sido destruídos por ordem do Ministério da Guerra ${ }^{6}$. Essa retração tinha como pano de fundo um pensamento anticomercial que o próprio Confúcio realçava em suas lições. O comércio era visto como uma atividade improdutiva (pensava-se que os comerciantes só trocavam as coisas de lugar) e o lucro uma motivação ignóbil e parasitária (FAIRBANK, 2008, p.106), ao contrário da visão que se tinha da agricultura, considerada a "fonte de riqueza do país” (p. 132). A isso se aliavam os interesses de uma elite letrada ligada ao imperador: percebia-se claramente que deixar o comércio florescer era, de algum modo, criar um poder fora do Estado ${ }^{7}$.

O Estado chinês sempre interferia na iniciativa privada - encampando atividades lucrativas, proibindo outras, manipulando preços, praticando a corrupção, restringindo o enriquecimento privado. Um alvo favorito era o comércio marítimo, que o reino celestial via como um desvio das preocupações imperiais, uma força desarticuladora e fonte de desigualdade de renda, pior ainda, um convite a sair do país (LANDES, 2003, p. 60).

A retirada chinesa - ou seu isolamento - ocorreu após 1474 e durante todo o século XVI foram levantados os muros que hoje são conhecidos como a

$6 \quad$ Segundo Landes (2003, p. 105), “foi tomada finalmente a decisão não só de cessar a exploração marítima mas também de apagar a própria lembrança do que tinha sido feito antes, para que gerações subseqüentes não fossem tentadas a repetir a insensatez”. [...] "em 1525, as autoridades costeiras foram intimadas a destruir todos os navios oceânicos e a prender seus proprietários. Finalmente, em 1551, passou a ser crime sair para o alto-mar num navio de múltiplos mastros, mesmo para fins comerciais".

Arrighi (2007, p. 330) tem opinião um pouco distinta, e ao tratar das viagens de Zheng He afirma que visavam o controle, pelo Estado, sobre o comércio exterior, donde se deduz que o Estado não seria contra o comércio. Afirma ainda que cessaram por serem caras demais e em razão das ameaças militares na fronteira norte (mongóis). 
Grande Muralha. Mas tal não se deu apenas pela aversão ao comércio. Uma outra peculiaridade cultural chinesa da época era a percepção que tinham de si mesmos. A história mostra que tal processo tende a acontecer sempre que alguma civilização ou nação se torna poderosa, o que era o caso da China. Os estrangeiros eram vistos como "bárbaros”, mantidos à distância (LANDES, 2003, p. 378), e o império como o “Império do Centro”, expressões que denotam a afirmação de superioridade e uma visão sinocêntrica do mundo (PINTO, 2000, p. 54). Em termos comerciais, esta percepção se consolidava ao comparar-se os produtos que à época a China tinha a oferecer com os produtos de outras regiões do mundo, menos avançados ou de qualidade inferior: era a confirmação de que nada do que vinha de fora podia interessar ao império celestial.

É interessante perceber que apesar da xenofobia, do sentimento de superioridade, a China foi invadida por diversas vezes, tendo dificuldades em se defender. Alguns tentam explicar esse paradoxo de uma civilização superior, porém militarmente fraca, em termos também confucianos. Hucker, citado por Fairbank (2008, p. 114), afirma que a China se tornara "tão civilizada que lhe faltavam valores marciais”. A burocracia, embora qualificada, era-o em termos administrativos e nutria aversão por guerreiros, vistos como brutos. Não se pode esquecer que esses letrados foram quase continuamente os assessores diretos do imperador e não lhes interessava dividir seu poder, ainda quando sob invasão, porque os invasores tinham a tendência a usar o corpo burocrático chinês, mais capacitado que o daqueles. Os invasores, não obstante, nunca conseguiram se impor como etnias e a tendência histórica era a de se adaptar à cultura chinesa e, de certo modo, "tornarem-se chineses”.

As relações da China com seus vizinhos, por outro lado, foram relativamente “cordiais” ao longo da história. Pinto (2000) fala em um sistema de "vassalagem em que praticamente todos os países da região pagavam tributos à China em troca de reconhecimento, de proteção militar e assistência, quando de situações de crise” (p. 56-57). Ao contrário dos conquistadores europeus, que buscavam a riqueza alhures, os chineses já possuíam muita riqueza e não sentiram a necessidade de dominar seus vizinhos ou países distantes. A influência chinesa na Ásia, segundo Pinto, seria de natureza mais cultural: 
A moldura política pretendida pelo império do centro, contudo, possuía caráter eminentemente cultural, sem o estabelecimento de presença política direta no Sudeste Asiático, sempre que seus vizinhos não representassem ameaça ao equilíbrio da área. Nesta perspectiva, a influência criada pela China era expressa pela sua incontestável superioridade em termos de organização política e social e produção de normas éticas de procedimento executadas exemplarmente pelos próprios chineses, na convivência entre nações. Não se procurava o domínio econômico ou a conquista territorial dos Estados vizinhos, com o emprego da força. Como resultado, o Sudeste Asiático tinha a percepção constante da existência de uma potência regional a ser levada em conta, mas não permanentemente temida (2000, p. 57).

A grandeza da China, com o tempo e em grande medida em razão do seu isolamento, foi sendo relativizada pela ascensão do poder europeu. As razões para essa "inversão” são múltiplas. Aniquilar seu próprio poder marítimo talvez tenha sido um dos maiores erros da história chinesa, ainda que o reino do centro não pretendesse se expandir e conquistar povos estrangeiros. Esta retirada criou um vácuo de poder que os europeus posteriormente ocupariam.

Contudo, as razões mais contundentes, a nosso ver, são dadas por Landes (2003) ao longo de toda sua obra. Argumenta que a China fechou-se para as idéias, para o conhecimento vindo de fora e, conseqüentemente, para o progresso, o aperfeiçoamento de técnicas, a inovação. Fala em “indiferença tecnológica”, em “xenofobia intelectual” num ambiente palaciano onde as inovações “eram julgadas por suas conseqüências para a ordem hierárquica” e não pela sua própria relevância em termos de evolução (2003, p. 383). Pioneira das inovações tecnológica, a China tinha dificuldades de aceitar que outros pudessem oferecer algo superior. A pólvora é o maior exemplo: os chineses a inventaram, mas os europeus a transformaram em instrumentos de dominação. 


\subsection{Um pouco de história}

Nosso argumento é o de que a China passou por um longo período de fechamento da dinastia Ming (século XV) até a morte de Mao Tsé-tung (século XX). Esse período, evidentemente, não foi uniforme, nem de absoluto isolamento ou autarquia, sem quaisquer contatos com o mundo externo, mas se pode dizer que estes contatos foram antes impostos que voluntários. Isto também não significa que inexistissem forças sociais e econômicas na China que defendessem o comércio, a abertura para o mundo, o contato com o ocidente; havendo inclusive notícias, no começo do século XX, da existência de uma burguesia nascente na China ${ }^{8}$.

O fato marcante é que a expansão européia, que havia começado por volta do final do século $\mathrm{XV}$, e que tinha como força motriz a busca de riquezas e posteriormente de mercados, havia atingido um novo estágio no século XIX. As pressões ocidentais sobre a China tornaram-se cada vez mais insustentáveis para o império. Após três anos de luta, a Grã-Bretanha venceu a Guerra do Ópio em 1842, uma disputa que envolvia basicamente interesses britânicos privados. O Tratado de Nanjing, que pôs fim ao conflito, representou apenas o começo da invasão ocidental (FAIRBANK, 2008): era o início da doutrina do open door (MAGNÓLI, 2004) e da era dos tratados desiguais, que impunham o livre comércio em determinadas partes do território - verdadeiros enclaves de dominação estrangeira. Posteriormente viriam japoneses, russos, franceses e alemães.

Deste modo, a “abertura” proporcionada pelas potências estrangeiras pontilhava escassamente o território e, diga-se mais uma vez, era uma imposição externa. Nessas situações, algumas classes se beneficiam e se enriquecem com o comércio e com outras atividades de natureza capitalista; todavia, dificilmente se poderia dizer se tratar de uma política nacional de abertura, de um projeto deliberado de inserção. Por esta razão consideramos todo o período como de fechamento, apesar do pequeno surto industrial e comercial criado.

\footnotetext{
$8 \quad$ Alguns dados interessantes em Fairbank (2008, p. 252): “Entre 1912 e 1920, observa Bergère, a indústria chinesa alcançou uma taxa anual de crescimento de 13,8\%. Dezenas de fábricas de algodão foram abertas na China, um total de 49 somente em 1922. Fábricas de trigo surgiram em Shangai, e indústrias de cigarro, papel e fósforos, nos arredores de Guangzhou.” E mais: "Durante a Primeira Guerra Mundial, a China também assistiu ao surgimento de modernos bancos chineses”.
} 
Esta invasão generalizada provocou feridas profundas na memória coletiva chinesa. Uma civilização que havia sido durante séculos a maior do mundo agora se via derrotada, humilhada, sem capacidade de se autogovernar. As reações não tardaram a vir e já no começo do século XX, Sun Yatsen liderava um movimento nacionalista em prol da autonomia. O período da República da China (1912-1949), porém, foi extremamente conturbado, tendo em vista, em primeiro lugar, a luta de Chiang Kaishek contra os "senhores da guerra" do interior para a consolidação do poder central, e em segundo lugar, a cisão que ocorreu no seio do movimento político a partir de 1927, quando o partido comunista se afasta do Kuomintang. Os dois partidos uniram-se posteriormente contra o invasor japonês e conseguiram expulsá-lo, em seguida voltando ao conflito para a tomada do poder. A vitória coube aos comunistas, que expulsaram o Kuomintang, tendo este último fugido para Taiwan.

A subida ao poder de Mao Tsé-tung, segundo Magnoli, pode ser compreendida como "uma reação violenta ao período de abertura da decadência Tsing e à subordinação do império do centro às grandes potências” (2004, p.269). De fato, o chamado “ciclo maoísta”, que se estende de 1949 a 1976 e do qual trataremos a seguir, representa talvez isolamento ou fechamento mais radical pelo qual um país já tenha passado na história mundial. Dentro do nosso instrumental de análise, é o ponto máximo a que chegou, o clímax a que chegou o isolamento chinês, representando ao mesmo tempo a perpetuação de um sentimento generalizado de superioridade e a reação - uma retração profunda - a quase um século de humilhações estrangeiras.

No plano histórico, o ciclo maoísta, que se estendeu até o início da década de 1970, representou um novo período de fechamento e isolamento. A natureza autocrática do poder comunista, ainda que singular, recuperou e atualizou inúmeros traços das dinastias tradicionais chinesas. $\mathrm{O}$ isolamento correspondeu a um projeto de definição de uma identidade nacional e à edificação de um aparelho de Estado capaz de controlar o território imenso e acolher o universo plural das culturas regionais. Com o regime brutal de Mao Tsé-tung, a China emergiu como unidade geopolítica centralizada e potência continental asiática. (MAGNÓLI, 2004, p. 269). 


\subsection{A China de mao}

Todos os números que dizem respeito a realidades chinesas são impressionantes, mas um deles ainda não está consolidado: o número de mortos decorrente das políticas maoístas ou simplesmente das inspirações de Mao. Embora a China tivesse passado por invasões estrangeiras, guerras civis, guerra de libertação e guerra intrapartidária para consolidar o poder central para tornar-se a República Popular da China, o que veio depois não foram anos de paz e prosperidade.

A premissa básica do novo poder na China era o papel central do Estado. O Estado volta a ser, mais uma vez, quase onipresente: quer tudo regular, em tudo intervém, planifica a economia e é liderado por um homem carismático, que ao longo do tempo se torna um deus por meio da propaganda que divulga seu culto e a crença na sua infalibilidade. É a volta do imperador - com nova roupagem, evidentemente. A ideologia comunista é o caminho, mas não se trata do comunismo de Marx, nem do soviético, e sim o de uma nova espécie, talhada pelo próprio Mao e tirada da experiência histórica chinesa. Como falar em proletariado em um país essencialmente agrícola?

A China retrai-se sobre si mesma para realizar uma tarefa dantesca: transformar um país recém saído da guerra, pobre, arrasado, por meio do fervor ideológico do seu povo e sob as ordens do seu novo líder. Esta tentativa durou quase trinta anos e seus resultados foram parcos, muitas vezes catastróficos em termos humanos. Vários episódios marcaram estes anos: a campanha das Cem Flores, a campanha Antidireitista, o Grande Salto para Frente e a Revolução Cultural. Analisálos, ainda que brevemente, é necessário para que se possa entender o que acontecerá em seguida.

A primeira tarefa foi a de coletivizar a agricultura. Este processo passou por diferentes etapas e foi concluído em 1958 com a criação das comunas (FAIRBANK, 2008, p. 327). Basicamente, os camponeses haviam passado da dominação dos grandes proprietários para a dominação do Estado, detentor do monopólio sobre a produção de grãos, indicando ao camponês quanto devia produzir 
e regulando os preços. O sistema não permitia que camponeses se apropriassem de qualquer parcela da produção, desincentivando o aumento da mesma. Ao longo do tempo, em período de crises políticas, os perseguidos do regime eram enviados às comunas para se "reeducarem".

A situação da indústria era semelhante. Após 1949, o processo de urbanização se intensificou um pouco, sobretudo em razão da migração de camponeses para a cidade, o que estimulou um pequeno crescimento industrial. Mas o sistema era de pequenas fábricas, ao contrário do soviético, que punha ênfase na industrialização pesada. O domínio do Estado no setor também era absoluto, com forte participação na direção das empresas de membros do partido, muitas vezes colocados ali em razão de seu fervor ideológico, e não por suas capacidades de administração.

Em 1956, após os acontecimentos da Hungria e da Polônia, Mao lançou a campanha das Cem Flores. A princípio tratava-se de um convite aos intelectuais para que fizessem suas críticas ao Estado, à administração, em suma, ao sistema. Os líderes comunistas talvez estivessem preocupados com as conseqüências de silenciarem uma parte importante da inteligência chinesa. Os intelectuais, professores, pensadores responderam ao chamado e durante dois meses fizeram suas críticas. Em seguida, caiu sobre eles uma repressão inesperada:

Dezenas de milhares de intelectuais foram expulsos de seus cargos, “mandados para baixo”, isto é, colocados em trabalhos humilhantes, como limpar as fossas em suas unidades de trabalho, encarregar-se das privadas públicas, ou foram transferidos para o interior para reeducação, realizando trabalhos manuais pesados em condições precárias. (MEZZETTI, 2000, p. $57)$.

Ainda se discute se a intenção de Mao era de identificar os que estavam contra o regime ou se a reação virulenta dos intelectuais contra as deficiências do governo é que provocaram, a posteriori, a repressão. Seja como for, a partir de então, Mao promoveu uma nova campanha destinada a expurgar os intelectuais do partido, fazendo críticas ao seu papel. Pela sua proximidade com os 
acontecimentos das Cem Flores, a campanha Antidireitista (1957-1958) pode ser considerada como a reação àquela.

Esta é uma característica dos anos maoístas: a ascensão ao poder de classes sociais menos educadas ${ }^{9}$, mas fervorosamente ligadas ao líder. Há uma intensificação crescente da aversão ao conhecimento. Slogans como “é melhor ser vermelho do que ser perito" iriam florescer nesse ambiente propício às maiores irracionalidades - um convite a que a ignorância tomasse as rédeas do Estado, já que os que detinham algum conhecimento possuíam o estranho hábito de tudo criticar.

O surgimento dessa nova classe revelou a profunda ignorância por parte da liderança do PCC em relação aos requisitos modernos. A economia e o crescimento do Estado exigiam mentes capacitadas. Preterir a elite intelectual em detrimento dos fundamentalistas foi um ato estúpido e desastroso. Em termos estruturais, destruiu o equilíbrio entre aprendizado e poder. [...] Mao e seus colaboradores cometeram erro após erro, pois treinaram mas não aproveitaram intelectuais experientes que, na equipe ou como colaboradores, poderiam ter evitado tantas incorreções. [...] $\mathrm{Na}$ contradição entre mérito e classe social, ele ressaltou a última. (FAIRBANK, 2008, p. 338).

Segundo dados do mesmo autor (2008, p. 337), “entre trezentas e setecentas mil pessoas capacitadas foram demitidas e receberam o título degradante de “direitistas”, inimigos do povo”. Na história chinesa, há um imperador que certa vez mandara queimar todos os livros do império e enterrar vivos todos os estudiosos. Seu nome era Shih Huang Ti. Mao Tsé-tung, referindo-se aos acontecimentos dessa campanha, costumava dizer: "Somos muito maiores do que Shih Huang Ti. Ele mandou enterrar somente 460 sábios, e nós enterramos pelo menos 46 mil” (MEZZETTI, 2000, p. 62).

9 Diz-nos Fairbank: "Em 1957, nas cidades e no campo, um novo grupo chegou ao poder formado por operários e camponeses com nível de escolaridade baixo, sem conhecimento sobre o mundo exterior, repletos de xenofobia e antiintelectualismo. [...] Este novo grupo que atingiu o poder no PCC menosprezava o aprendizado e era vingativo e capaz de destruições cruéis e fanáticas quando tinham oportunidade. Possuíam pouquíssimas noções dos problemas de modernização da China e de como solucioná-los”. (2008, p.338). 
A ênfase na paixão ideológica como critério para a transformação, combinada com a expulsão dos intelectuais e técnicos mais capacitados do governo, levou a nova empreitada de Mao, o Grande Salto Adiante (1958-1960), a um fiasco de proporções humanas extraordinárias. Segundo dados de Fairbank (2008, p. 339), cerca de 20 a 30 milhões de pessoas morreram de fome no período ${ }^{10}$. A idéia era mobilizar as massas, com a criação de comunas e a intensificação do trabalho nas cidades para transformar a aparência da China com a construção de estradas, rodovias, cidades, represas etc. Provavelmente os resultados econômicos pífios conseguidos até então foram a razão para o despertar dessa vontade.

Ao grito de slogans como "superar a Inglaterra em 15 anos", "mobilizar todas as energias, mirar ao alto, construir o socialismo melhor, mais velozmente e a menor custo”, foram mobilizados cerca de 650 milhões de chineses para efetuar o trabalho pesado (FAIRBANK, 2008, p. 341). Era a velha aposta no fervor revolucionário como motor das grandes mudanças ${ }^{11}$. Houve uma pequena descentralização, mas os encarregados das comunas, das empresas locais e outras entidades não eram especialistas ou técnicos, e sim líderes comunitários, mais “vermelhos do que peritos”.

Era a coletivização da vida como um todo, em termos militares, com a força de trabalho dividida em batalhões, companhias, brigadas e regimentos. Houve um esforço gigantesco para as grandes obras de irrigação, mas como devido à campanha antidireitista do ano anterior não era politicamente aceitável utilizar os técnicos, que na maioria haviam sido "mandados para baixo” e ali deviam permanecer, era preciso confiar no ardor ideológico e revolucionário e não na competência específica. (MEZZETTI, 2000, p. 61).

10 Mezzetti (2000, p. 66) é mais “moderado”: estima que foram 20 milhões.

11 Sobre esta peculiaridade da psicologia maoísta, diz Simon Leys, citado por Mezzetti: "O Grande Salto Adiante cristalizou os impulsos mais negativos e destrutivos do ego maoísta: a subjetividade lírica do esteta visionário que ignora as contingências da realidade; a intolerância do artista inspirado diante da matéria que não se deixa plasmar; o idealismo voluntarista que tenta substituir com energia mística os meios oferecidos pela ciência e pela técnica; a desconfiança camponesa com as inovações modernas; a sistemática valorização dos aspectos mais retrógrados do país. Reconhecem-se aqui as velhas formas da guerrilha conduzida no isolamento primitivo das províncias do interior, fórmulas que haviam assegurado a Mao as mais fulgurantes vitórias. Ele não percebeu, no entanto, que os problemas da edificação de uma China moderna nos anos 1950 eram radicalmente diversos” (2000, p. 64). 
A catástrofe esteve envolta em aspectos tragicômicos. Quis se produzir aço, ferro, gusa por toda parte, nos chamados “fornos de quintal” e a matéria prima, por vezes, foi a maçaneta das portas, os utensílios de cozinha ou qualquer coisa que pudesse ser fundida, até radiadores de sistemas de aquecimento (MEZZETTI, 2000, p. 63). O mesmo autor conta que Mao desferiu uma campanha contra o que chamava de "os quatro males": ratos, moscas, pássaros e mosquitos, o que alterou desfavoravelmente o ecossistema, visto que muitos desses animais são predadores de insetos que costumam danificar colheitas (2000, p. 65).

A produção agrícola despencou, calamidades naturais atingiram a China à época e, para completar, a União Soviética retirou técnicos e ajuda financeira no mesmo período, em razão do cisma sino-soviético. Este completo fracasso deu ensejo a uma pequena reviravolta no interior do partido, com algumas medidas políticas que tinham por finalidade afastar Mão Tsé-tung do poder. Este objetivo foi em certa medida alcançado $^{12}$, passando a China por um curto período de tempo a se recuperar economicamente.

No entanto, em 1966, Mao retorna ao poder num dos movimentos mais complexos e aterrorizantes da história chinesa, a Revolução Cultural (19661976). Todos estes acontecimentos - cada um deles - dariam obras inteiras e ainda assim talvez não fossem integralmente compreendidos. Há um certo consenso segundo o qual Mao teria lançado os slogans da Revolução Cultural para, mais uma vez, mobilizar as massas e voltar ao poder, o que conseguiu fazer ${ }^{13}$. Desta feita, o ataque era feito contra as instituições que queriam frear a revolução, contra o sistema que ele mesmo havia criado, com incitações aos jovens para "bombardearem o quartel-general”, para “aprenderem a revolução fazendo a revolução” e para que a revolução fosse um movimento constante.

Os estudantes responderam ao chamado, fechando universidades, criando a famosa Guarda Vermelha, que aterrorizou professores, intelectuais,

12 Na China quem detém o poder não necessariamente está ocupando o topo da hierarquia oficial. Mao Tsé-tung, apesar de seu breve afastamento, foi o líder inconteste da China de 1949 a 1976, como seria Deng Xiaoping daí até a sua morte, embora num determinado momento tenha deixado todas as suas funções oficiais.

13 O resumo que faz Mezzetti é irretocável: “A Revolução Cultural, indubitavelmente um grande movimento de massa, foi essencialmente uma luta pelo poder lançada por Mao para reconquistá-lo, instrumentalizando o descontentamento das multidões que ele fora o primeiro a submeter à exaustão, à fome e ao chicote” (2000, p. 78). 
membros do partido, realizando "processos públicos”, humilhando milhares de pessoas, e muito mais - tudo isto sob o sopro de inspiração de um único homem. $\mathrm{Na}$ mesma época, embora Mao continuasse sendo o líder, a cúpula do poder fora tomada por quatro personagens próximos a Mao, entre os quais a sua mulher. Este pequeno grupo ficou conhecido como o Bando ou Gangue dos Quatro.

O saldo, como sempre, impressiona: cerca de 400 mil pessoas mortas por maus tratos (FAIRBANK, 2008, p. 355) e 60\% dos membros do partido eliminados. Quando o Bando dos Quatro foi julgado após a morte de Mao, foi incriminado por ter perseguido 700 mil pessoas e condenado 35 mil à morte. Mas a quantidade dos que fugiram ou que desapareceram só foi sendo revelada aos poucos, quando todas essas pessoas foram reabilitadas sob Deng Xiaoping.

\subsection{Política Externa}

Muito do que ocorreu na China maoísta parece ter sido uma reação violenta de um país contra tudo o que viesse de fora. Nada mais natural: de fora vieram humilhações, dominação, dependência e morte. Junte-se a isso o fato de ter sido por séculos a maior civilização do mundo, e não é difícil compreender a intensidade da reação do povo, ainda mais quando seus líderes defendiam agora a independência e uma mudança para transcender o antigo estado de pobreza, de dependência, de guerra e miséria.

Não se trata de justificar políticas públicas, que foram indubitavelmente desastrosas; trata-se de compreender as motivações de um povo e de seus líderes. A política externa do período maoísta foi a representação externa de um sentimento interno de isolamento, de retração, de afastamento da sociedade internacional. Após um período que foi, seguindo Pinto (2000, p. 71), de consolidação da República Popular (1949-1958), os desenvolvimentos internos conturbados geraram desconfiança e temor entre vizinhos: a China passava a ser um fator de instabilidade para a região.

Yahuda (1983) entende que era a transição de um país considerado o "sick man of Asia” para um Estado que, externamente, queria ingressar no clube das 
grandes potências. Esta vontade gerava não só desconfianças ${ }^{14}$ como atritos. Num intervalo de vinte anos, a China contribuiu significativamente para o recuo das tropas americanas na Guerra da Coréia, tornou-se uma potência nuclear (1964), rompeu com a União Soviética e fez uma aliança com os Estados Unidos (início da década de 1970) para contrabalançar o poderio soviético (YAHUDA, 1983, p. 651), tendo a partir de então assumido sua cadeira como membro permanente no Conselho de Segurança das Nações Unidas, substituindo Taiwan.

O enfoque na segurança militar era natural. Recorde-se a proximidade temporal das invasões ocidentais e japonesas. Além disso, havia a Rússia: ainda quando os chineses lutavam para se libertar do Japão, os russos apoiaram abertamente o Kuomintang, o que gerou desconfianças que nunca foram completamente eliminadas. O revisionismo da era Kruschev, a maneira como os russos resolveram o problema húngaro - que não era de bom augúrio para a China - a recusa em apoiar os chineses na crise do estreito de Taiwan em 1958, a retirada dos técnicos em 1960 e a relutância dos soviéticos em aceitar que a China possuísse armamentos nucleares foram motivos de discórdia.

Além do mais, a República Popular da China nasceu cercada de inimigos, antigos e novos. Entre estes últimos, os Estados Unidos naquele momento eram os mais poderosos: haviam feito a guerra na Coréia, apoiaram o regime de Formosa (Taiwan) e posteriormente o Japão, o maior de seus inimigos, que cometera atrocidades até hoje não esquecidas pelo povo durante a invasão de seu território.

A mudança mais interessante ocorreu com a aproximação americana. Se anteriormente a ideologia comunista ainda constituía um fator de apoio aos soviéticos, parece que o paradigma realista se impôs nos anos 70. Tanto para os Estados Unidos quanto para China o poderio da URSS preocupava. Segundo Kim (1981, p. 438), "the logic of growing military and strategic ties between China and the United States is based on the unstated norm that guides the practitioners of the balance of power game - the enemy of our enemy is our friend”.

Todos estes aspectos demonstram o isolamento chinês no âmbito de suas relações internacionais. Se contato havia, era cercado de desconfianças, de

14 Sobre as desconfianças, afirma Yahuda: "China has also experienced difficulty in establishing consistently good workable relations with others. With the exception of Pakistan, all China's alliances have ended in acrimony” (1983, p. 651). 
visões estratégico-militares. Não havia chegado a hora de os chineses fazerem as pazes com o mundo: teria que esperar que suas feridas internas fossem completamente curadas para dar o salto, ou melhor, para readquirir, perante si mesma e perante a sociedade das nações, seu anterior status. 


\section{FISSURAS NO MURO: A TRANSIÇÃO DE DENG XIAOPING}

O período pós-maoísta, ou a “era” de Deng Xiaoping, representa um momento de ruptura radical com todo o longo caminho de fechamento que identificamos anteriormente. As reformas empreendidas foram amplas e abarcaram as mais diversas instituições, do pensamento confucionista às relações internacionais. O final dos anos setenta corresponde ao início de uma abertura para o mundo, de uma reconciliação, poder-se-ia dizer, entre a China e o mundo. Interessa-nos estudar esta transição para podermos indagar, ao final, se o momento atual configura uma continuidade da era reformista de Deng ou se há indícios de uma nova ruptura.

\subsection{O papel da liderança na China}

O autor do presente trabalho não acredita que a história do mundo seja a história dos líderes. Esta visão mítica cede lugar aos fatos, às conjunturas e estruturas políticas, econômicas e sociais que são as “forças profundas” da história. Não obstante, ao se estudar a história da China, tal crença sofre um abalo sísmico. Nenhuma outra história parece estar tão vinculada, e sobretudo há tanto tempo, à vontade de suas lideranças.

É evidente que se a China é o que é hoje, foi a força do seu povo que a trouxe até aqui. Mas não menos evidente parece ser esta outra constatação: que se algum outro líder quisesse levá-la à direção oposta, o povo o teria seguido na direção oposta. Causa espanto a capacidade que tem uma população tão imensa de abraçar a causa do líder, de levar adiante a sua bandeira. Contestações sempre houve; repressão também. Mas a China, no geral, seguiu seu líder. Explicações para este fato não são de nossa alçada: são de natureza sociológica, cultural, antropológica talvez. Trouxemos alguns subsídios para explicá-lo no primeiro capítulo, embora nem aquelas poucas idéias nos satisfaçam. Fairbank, tratando do que ocorrera durante a Revolução Cultural, indaga-se sobre a mesma problemática:

Analisando a Revolução Cultural, somos então obrigados a imaginar uma sociedade que pode ser dirigida por um Grande Líder e por um partido ditatorial porque os cidadãos são politicamente passivos e obedientes à 
autoridade. Eles não possuem direitos humanos, pois foram ensinados que a reivindicação destes seria considerada uma atitude egoísta e anti-social e, portanto, desprezível. E também seria severamente punida. O problema começa no âmbito da vida familiar das províncias chinesas, onde os ensinamentos confucianos sobre ordem social por meio da obediente autosubordinação deixaram suas marcas até hoje. (2008, p. 252).

Quaisquer que sejam as causas, o fato permanece, e uma de suas comprovações mais cabais ocorreu justamente na transição do final dos anos setenta. Não poderia haver duas personalidades tão distintas quanto as de Mao e Deng, assim como suas políticas, como será demonstrado, foram radicalmente diferentes. E, no entanto, a China seguiu o primeiro. E o segundo. Seguiu o primeiro, ainda que por diversas vezes suas políticas tenham resultado em fome, miséria, derramamento de sangue e humilhações; seguiu o segundo quando um pouco de liberdade lhe foi concedida - ao menos a liberdade de enriquecer.

Não se trata de idealizar o homem. Deng Xiaoping foi companheiro de Mao durante todo o período revolucionário, foi soldado e político, participou das lutas de independência, foi um dos responsáveis pela campanha antidireitista dos anos cinqüenta e estava no poder em 1989, quando do episódio dramático da praça Tiananmen. Foi defensor de reformas econômicas importantes, que transformaram radicalmente a China, mas continuou sendo o defensor de um regime político fechado. Talvez esse ponto seja um dos poucos que o aproximem de Mao.

Fizemos esta pequena digressão para que não se pense que estamos a contar uma história de vilões e heróis, com enfoque na personalidade dos líderes. O que pretendemos deixar claro, entretanto, é que as características inerentes à cultura chinesa e às tradições do seu povo nos obrigam a tratar daqueles que manobraram o poder. Seus incentivos à ação moldaram os comportamentos da massa. Arriscaríamos um palpite: o de que não há história nacional no mundo que mostre uma “sensibilidade” tão grande entre líder e povo, um acatamento maior à liderança, para o bem e para o mal ${ }^{15}$.

15 Schram, ao tratar de acontecimentos de massa em 1979, faz a seguinte afirmação: “despite the categorical statement, in early 1979, that "campaigns" or "movements" would no longer be launched in China, the Chinese people are still so deeply marked by the reflexes created previously 


\section{2. "Revoluções de cima”}

Em decorrência do que foi dito, é preciso entender que as reformas ocorridas na china pós-maoísta foram idealizadas por membros do mesmo partido comunista de Mao, o PCC. Tais reformas, contudo, foram tão profundas e abalaram paradigmas tão antigos, que poderíamos dizer que constituíram uma verdadeira revolução. Não uma revolução no seu sentido clássico, como foram a Francesa e a Russa, com ampla participação popular, mas uma “revolução vinda de cima”, como a definiu Mezzetti (2000, p. 369) ${ }^{16}$.

Mao designou seu sucessor, Hua Kuofeng, que a partir da morte daquele em 1976, tentou estabelecer uma política que conservasse as idéias do Timoneiro, logo conhecida como a política dos “dois quaisquer”, isto é: 1) qualquer coisa que Mao tivesse dito deveria ser obedecida; e 2) qualquer decisão que tivesse tomado deveria ser mantida. Em grande medida, tal estratégia visava manter Deng Xiaoping afastado do poder ${ }^{17}$.

Todavia, o grupo político de Deng havia se fortalecido após todos desastres causados pelas políticas maoístas. Muitos dos membros foram perseguidos durante a Revolução Cultural e não tinham a intenção de voltar ao passado ou deixar que o sucessor de Mao perpetuasse gestos e atitudes típicas de sua época, como a mistificação do líder.

O final dos anos setenta e início dos oitenta foi um período de luta intrapartidária que definiu o que a China seria daí para frente. Foi realizada uma “desmaoização” em todas as esferas do Estado. Era preciso se desvincular de Mao aos poucos, sem criticá-lo abertamente, ao menos no início. Deng utilizara-se a princípio de trechos de discursos do próprio Mao para enfatizar que os novos membros não abandonavam o antigo líder, mas realizavam uma interpretação do seu pensamento conveniente às mudanças que pretendiam empreender:

that, as soon as a target is designated, they all feel their loyalty and activism are being tested in a campaign, and respond very much as they did to the calls of the past (1984, p.440).

16 Bergère utiliza uma expressão mais amena: "une réforme autoritaire menée d'em haut" (1993, p. 4).

Mao o havia afastado por duas vezes durante a Revolução Cultural. 
The fundamental point of Mao Zedong Thought is seeking truth from facts and integrating the universal truth of Marxism-Leninism with the concrete practice of the Chinese revolution. Comrade Mao Zedong wrote a four word motto for the Central Party School in Yan'an: "Seek truth from facts”. These four words are the quintessence of Mao Thought. (SELECTED WORDS) ${ }^{18}$.

O novo slogan era procurar a verdade nos fatos: o pragmatismo dera lugar à ideologia, ao fervor ideológico e aos dogmas. A "Grande” Revolução Cultural vai sendo minada aos poucos nos jornais do partido até ser considerada um “desastre”, um “caos” (MEZZETTI, 2000, p. 175); as responsabilidades vão sendo direcionadas para o timoneiro, embora se reconhecesse sempre seu papel como grande revolucionário; todos os erros são pouco a pouco apontados. Em 1981, o Comitê Central do partido Comunista, revisando a história do partido, identificou oficialmente cinco erros de Mao, entre os quais: ele teria "mal-dirigido" a campanha antidireitista de 1957; fora o responsável pelos erros cometidos durante o Grande Salto Adiante e pelo programa das Comunas; fora o principal responsável pela Revolução Cultural, “seu maior erro”, durante a qual teria se divorciado “do partido e das massas” (CHAI, 2003, p. 167).

A difamação gradual das políticas de $\mathrm{Mao}^{19}$ deve ser enxergada como uma maneira de, ao mesmo tempo, não chocar os antigos partidários do líder, ainda ocupantes de posições dentro do partido e alhures, e de dissociar o que era culpa do partido do que fora culpa de sua liderança maior. Em outras palavras, um culpado pelas catástrofes deveria haver, senão necessariamente seria todo o partido comunista, que ainda se mantinha no poder. Por esta razão é que foram julgados e condenados como criminosos os que formavam o Bando dos Quatro, por exemplo. Os líderes buscavam reconciliação com o povo, promovendo uma transição que

\footnotetext{
$18 \quad$ Discurso realizado em 16 de setembro de 1978.

19 Um dos maiores exemplos dessa difamação foi a crítica a Dazhai. Dazhai era a "fazenda modelo" de Mao, uma localidade rural que era utilizada como o exemplo perfeito de que as políticas comunistas funcionavam. Neste período comprovou-se que se tratava de uma farsa. Diz-nos Bonavia, citado por Dittmer: “The Dazhai model was impugned by revelations that the heroic brigade too had received abundant largesse from the state, had been falsifying production statistics for years, and their Promethean projects were economically irrational, a piece of stupidity” (1981, p. 34).
} 
punisse culpados, que apontasse seus bodes expiatórios para que a nova liderança pudesse continuar suas reformas com um pouco mais de legitimidade.

Na execução dessa tarefa, Deng Xiaoping mostrou toda sua habilidade política. Não havia surgido de repente: sempre fora uma voz "diferente” dentro do partido: mais pragmática, realista, e por esta razão havia sido por duas vezes afastado por Mao. Também não estava só: muitos líderes colocaram-se do seu lado, mas a batalha interna foi intensa até que se consolidasse seu poder. Assim como Mao, soube utilizar as massas a seu favor. Quando em 1978 se formou nas ruas de Pequim o "muro da democracia”, um local onde as pessoas escreviam qualquer coisa que quisessem contra o partido, Deng, aproveitando-se de um momento de fraqueza em sua posição, apoiou o movimento, criticou o passado etc. Quando, porém, já havia se firmado como líder inconteste e as manifestações se tornaram um pouco mais ácidas, não tardou a lançar seus "quatro princípios fundamentais"20 e a reprimir o movimento com várias prisões e condenações.

Em 1978 realizou-se o Terceiro Plenário do Comitê Central do PCC. Este encontro representa, segundo Mezzetti, o "ponto nevrálgico para a mudança” (2000, p. 44) e é citado na quase totalidade dos textos que tratam da transição chinesa do período. Foi neste Pleno que Deng trouxe à luz boa parte do seu pensamento reformista, e nele também foram "reabilitadas" grande parte das vítimas tanto da Revolução Cultural quanto do Grande Salto Adiante - mais um aspecto de conciliação com o povo. Só um pouco mais tarde, em 1980, os novos líderes, segundo Yee, estariam completamente fortalecidos e demonstrariam que as preocupações da China tinham mudado do âmbito político para o econômico: ${ }^{21}$

The fifth Plenary Session of the Eleventh Central Comittee, held in February 1980, successfully removed the "whatever" faction from power. The eventual demotion of Hua Guofeng and the ascendancy of Zhao Ziayang as

\footnotetext{
20 “1) Prosseguir no caminho do socialismo; 2) Apoiar a ditadura do proletariado; 3) Apoiar a orientação do partido comunista; e 4) Apoiar o marxismo-leninismo e o pensamento de Mao" (MEZZETTI, 2000, pp. 120-121.

21 Sobre esta mudança, em particular, consultar OKSENBERG (1982) e SCHRAM (1984). O título do artigo deste último é, significativamente, "Economics in command? Ideology and policy since the Third Plenum, 1978-84". Sobre a mudança, afirma Terril: "If the hope of the cultural revolution was for good politics, the hope of the post-Mao era is for prosperity and good economics" (2005, p. 66).
} 
the Premier and Hu Yaobang as Party Chairman completed Deng's strategy to eliminate "leftist" elements among the top leadership. The new leadership declared that class struggle was no longer essential in China because its socialist transformation was fundamentally completed. To concentrate on economic construction was regarded as a crucial "strategic shift" that China must make and from which it must never deviate except in the event of large-scale invasion by a foreign enemy (1983, p. 248).

\subsection{Revolucionando o pensamento}

Os discursos de Deng Xiaoping talvez sejam a melhor fonte de consulta para se perceber o quanto a mudança, antes de mais nada, passava por uma revolução nas mentalidades. Os slogans agora eram "emancipar a mente”, "procurar a verdade nos fatos", a "prática como único critério da verdade”, etc. Todos os motes levam à conclusão de que a doutrina não importava mais. Segundo Mezzetti, Deng era "alérgico" a qualquer tipo de ideologia (2000, p. 14). Já em 1962 havia feito a famosa afirmação de que não importava a cor do gato, contanto que fosse capaz de caçar ratos. Nesse sentido, Deng não foi o sucessor de Mao, mas seu "usurpador e carrasco” (MEZZETI, 2000, p. 15):

Mao fizera da China uma imensa caserna e convento, sem a funcionalidade da primeira e a espiritualidade do segundo; seus habitantes estavam condenados à miséria vermelha pela soldadesca privilegiada ou pelos guardiãs trogloditas da ideologia condensada nos livrinhos agitados por toda parte. Coma ordem de "buscar a verdade nos fatos, não nos preceitos”, Deng fez com que fechassem os livrinhos, desmantelou as casernas, escancarou as portas do convento e transformou os habitantes em corsários do capitalismo ao grito de “enriqueçam!” (2000, p. 15).

A destruição do culto à personalidade do líder, outra herança mental maoísta, resta demonstrada nos sucessivos artigos do governo: 
Em nossas fileiras, alguns, por má-fé, atribuem sempre todas as conquistas e todas as vitórias aos indivíduos, exagerando seu papel. A divinização de um indivíduo e o culto da personalidade foram gerados pelo exagero do papel do próprio indivíduo. [...] Quando um indivíduo é capaz de resolver tudo, o partido e o Estado caem sob sua vontade. [...] O resultado é que não apenas é difícil evitar erros, mas o desastre torna-se inevitável (MEZZETI, 2000, p.182).

Se a sabedoria de um líder é inexaurível, sua teoria absolutamente correta, sua estratégia absolutamente eficaz e seu papel decisivo, nesse caso não é uma pessoa normal. É o Deus supremo. [...] Tudo ficou petrificado. As massas foram suprimidas ou reprimidas. Aprendemos a lição e não devemos cair novamente no mesmo, se desejarmos as quatro modernizações. A direção coletiva deve ser a regra suprema (2000, p. 188).

Não só o culto à personalidade foi aos poucos destruído, como o próprio Deng, à medida que o tempo avançava, foi se retirando das posições de poder, incitando a renovação dos quadros, chamando de volta os técnicos e intelectuais. Este último fator foi essencial para a realização das "quatro modernizações” de Deng, o seu grande objetivo ${ }^{22}$. De fato, uma administração que se queria moderna necessitava de pessoas capacitadas. Deng tratou de trazer de volta os técnicos e intelectuais expurgados, assim como passou a incentivar estudos, tanto na China quanto no exterior. O saber já não era mais um delito social (MEZZETTI, 2000, p. 133) e não se tratava agora de ser mais vermelho do que perito:

Quem contribui para o desenvolvimento da ciência, mesmo sem dar atenção à ideologia, dá o melhor apoio ao objetivo primordial da política de modernização. Neste sentido, é "vermelho em si e por si” (MEZZETTI, 2000, p. 96).

Esta volta fazia parte, também, da política de conciliação com o povo chinês. Dados de Mezzetti indicam que em 1980 mais de cem milhões de pessoas foram "reabilitadas” (2000, p. 166). Era o retorno de desaparecidos, “direitistas”,

22 Agricultura, indústria, defesa e ciência. 
“inimigos do povo”, intelectuais, professores, técnicos e as mais diversas categorias de exilados e foragidos do regime de Mao. Os intelectuais eram revalorizados porque a ciência em si era revalorizada, readquirindo o conhecimento sua antiga importância. Num discurso já em 1977, Deng afirmava:

The key to achieving modernization is the development of science and technology. And unless we pay special attention to education, it will be impossible to develop science and technology. Empty talk will get our modernization program nowhere; we must have knowledge and trained personnel (SELECTED WORDS).

Mas a maior mudança em termos mentais certamente é a que foi apontada nas duas citações iniciais deste trabalho. Uma sociedade que durante séculos a fio aprendeu que o lucro era "pecado", que buscar a riqueza era errado, que os negociantes eram seres inferiores, agora escutava seu líder maior dizer, em alto e bom som, que enriquecer era glorioso. Mais uma vez, o povo seguiu seu líder e a explosão de atividades privadas, de negócios, combinados com incentivos tipicamente capitalistas, que serão estudados na próxima seção, provocou as altas taxas de crescimento econômico da China contemporânea ${ }^{23}$. O Primeiro Ministro, Hu Yaobang, discorria em 1984 (SCHRAM, 1984, p. 454):

The primary concern of our policies must be to enrich the peasants as fast as possible. If the peasants become prosperous, the people's realm will be stable. Do not fear prosperity. ${ }^{24}$

A dificuldade seria justificar essa transformação do pensamento com o repúdio ao capitalismo. Mas os chineses são mestres da adaptação teórica. Muito rapidamente expressões como "socialismo de mercado",25, “socialismo com

23 Elisabeth Wright, citada em Arrighi, comenta: "O dinheiro substituiu o marxismo como Deus da China” (2008, p.31).

$24 \quad$ Gurtov e Hwang apontaram, num estudo da mesma época, alguns objetivos da política externa chinesa, entre os quais destacamos o de $\mathrm{n}^{\circ} 3$ : "economic performance is considered by chinese leaders to be the key to national security and international legitimacy” (ZHI, 1982, p. 2).

25 Pinto tenta definir a "economia socialista de mercado" nos seguintes termos: "representa tentativa de obter-se equilíbrio entre valores de igualdade - socialistas - e de eficiência - mercado. Nessa perspectiva, almejar-se-ia permitir que as pessoas enriqueçam, tendo sempre em vista a 
características chinesas” surgiram. A verdade é que a esfera do discurso na China nunca foi tão importante quanto a simbiose entre vontade do líder e ação popular. Os chineses não estavam preocupados com tais discussões; se lhes eram dados os incentivos para enriquecer, tornar-se-iam ricos.

\subsection{Revolução na prática}

Paralelamente às novas idéias e aos novos paradigmas de pensamento, reformas importantes foram realizadas. Em sua ampla maioria, visaram dar incentivos de natureza privada aos agentes econômicos para que saíssem de sua situação de miséria e “enriquecessem”. Na agricultura, estabeleceu-se um "sistema de responsabilidade” no qual pela primeira vez os camponeses podiam reter para si parte dos lucros, comercializar parte dos seus produtos, sem o antigo controle de excedentes (ARRIGHI, 2008, p. 366). Houve abolição das comunas e restituição das terras aos camponeses num sistema que, segundo Mezzetti, assemelhava-se ao da enfiteuse (2000, p. 201). Além do mais, a diversificação era agora permitida, o que significou que a produção deixou de ser só de cereais, como na época de Mao, voltando-se para produtos cujo mercado demandava em maior escala, isto é, produtos mais lucrativos.

$\mathrm{Na}$ indústria, passou-se a incentivar a busca eficiente dos lucros, com pessoas dotadas de capacidade administrativa e comercial à frente das empresas, mais um sinal da inversão da preponderância do "vermelho" sobre o "perito”.

Deng consistently advocated rectification of the top management in factories. He repeatedly stressed that factory managers had to be competent, that orderly and effective rules and regulations should be instituted in all

prosperidade comum como uma meta socialista a ser atingida, bem como tomando precauções no sentido de evitar hiato crescente entre setores sociais distintos, problema esse não superado nos países do ocidente” (2000, p. 18). E continua: "Em suas linhas principais, a economia socialista de mercado seria caracterizada por três aspectos: a propriedade estatal de $51 \%$ dos setores estratégicos da economia, entre estes o de energia, telecomunicações, produção de armamentos, aço, etc; um sistema de assistência social aos trabalhadores em que haveria divisão de responsabilidades entre o governo e as empresas - algo nos moldes do existente no Japão; o planejamento macroeconômico a longo prazo permanece responsabilidade do governo central, enquanto as decisões relativas às decisões empresariais, em nível micro, ficam sujeitas às forças de mercado” (p. 19). 
production units. Workers were to be rewarded for their production and not their politics (BACHMAN, 1986, p. 303).

Como método para uma reforma salarial que incentivasse a produtividade entre os trabalhadores, Deng começa, a partir de 1978, a enunciar o princípio de “distribuição segundo o trabalho da cada um” e a instauração do sistema de bônus (BACHMAN, p. 305). Todas essas modificações visavam a recompensar o mérito, a competência e, sobretudo, o resultado, afastando todo e qualquer critério de natureza ideológica.

O novo governo promoveu uma pequena descentralização das atividades para o âmbito local, além de criar as famosas Zonas Econômicas Especiais em diversas localidades. Em tais zonas, a liberdade para produzir era mais ampla, as barreiras quase inexistentes e os incentivos enormes. O sistema de joint-ventures ${ }^{26}$ permitiu que empresas chinesas, ao se aliar às estrangeiras, adquirissem os conhecimentos tecnológicos necessários para alcançar estágios mais avançados de produção $^{27}$. Segundo Fairbank:

A fim de atrair investimentos externos, o governo oferecia benefícios fiscais especiais, regulamentos flexíveis e opunha menos obstáculos do que em qualquer outro lugar do país; em contrapartida, as zonas deveriam produzir novas tecnologias e promover exportações (2008, p. 378).

Associada a esta tentativa de atração de investimentos externos estava a idéia, também nova, de que o conhecimento tecnológico vindo do exterior não era mais estigmatizado. "Technology is now claimed to have no class character; rather, it is treated as an international collective good. What used to be called exchange of unequal values has now become international trade practices and norms" (KIM, 1981, p. 449). Para um país que durante milênios rejeitou o conhecimento estrangeiro porque supostamente inferior, a mudança foi radical.

\footnotetext{
26 A lei sobre joint-ventures foi aprovada em 1980 (MEZZETTI, p. 346).

$27 \quad$ Quanto aos objetivos de tais zonas, acrescenta Mezzetti: “O objetivo não era apenas atrair capitais para criar postos de trabalho, mas sobretudo atrair tecnologia, técnicas de organização e de gestão que pudessem em seguida difundir-se no país; em uma palavra, a cultura empresarial” (2000, p. 347).
} 
Houve também desregulamentação e privatização na China de Deng. No entanto, Arrighi faz um alerta no sentido de que tais políticas não foram efetuadas de forma rápida e inconseqüente: a mão do governo estava tão presente quanto a mão “invisível” do mercado:

A desregulamentação e a privatização foram bem mais seletivas e avançaram em ritmo bem mais lento do que nos países que seguiram a receita neoliberal. Na verdade, a principal reforma não foi a privatização, mas a exposição das empresas estatais à concorrência de umas com as outras, com as grandes empresas estrangeiras e, acima de tudo, com uma cesta de empresas privadas, semiprivadas e comunitárias recém-criadas. [...] O papel do governo chinês na promoção do desenvolvimento não diminuiu. Ao contrário, o governo investiu quantias enormes no desenvolvimento de novos setores, na criação de novas Zonas de Processamento de Exportações (ZPEs), na expansão e modernização da educação superior e em grandes projetos de infra-estrutura, num nível sem precedentes em nenhum país de renda per capita comparável (2008, p. 362).

O novo sistema era híbrido, é importante que se diga. Há uma tendência, sobretudo por parte dos pensadores liberais, de tratar o tema da abertura chinesa com uma ênfase muito grande no mercado, sem atentar para o papel central que o Estado exerceu nessa transição. Todas as reformas, de fato, liberaram uma força imensa de produção, que há muito vivia aprisionada por políticas e por uma mentalidade cultural avessas ao comércio e ao lucro, mas o Estado representou o papel de propulsor da abertura ao mesmo tempo em que a regulava, tomando medidas de forma gradual, inclusive fiscalizando os resultados ao longo do processo e fazendo os ajustes ${ }^{28}$, quando necessário. Cheng (1985, p. 110) atenta para o fato numa periodização que faz sobre as reformas, tendo as relativas a agricultura começado em 1978 e as da indústria só a partir de 1984, embora os discursos de

\footnotetext{
$28 \quad$ Diz Arrighi: "Quando a China se liberalizou, foi gradualmente, de modo a assegurar que os recursos humanos deslocados fossem reaproveitados em uso mais eficiente e não deixados num desemprego infrutífero" (2008, p. 30). Na visão de um outro autor, as mudanças na economia chinesa representam "a very careful two steps forward, one step back, all the time very carefully calibrated" (MACFARQUHAR, 1987, p. 29).
} 
Deng indiquem sua vontade de tudo modificar desde anos bem anteriores. Pinto aponta algumas das conquistas adquiridas com essa ampla rede de reformas:

Formou-se um mercado com mecanismos próprios de preço para cerca de 80\% da produção agrícola e industrial; a estrutura de intervenção do Estado na economia alterou-se, de forma que cerca de metade do PNB seria resultado de empresas privadas; o setor estatal, por outro lado, contaria com autonomia crescente para tomar decisões segundo a demanda de mercado; o sistema do "grande pote", segundo o qual deveria ser igual a remuneração para qualquer tipo de trabalho foi substituído por ampla variação salarial, com ênfase no esforço intelectual, e mobilidade econômica; o rígido esquema de planejamento central, a partir de Pequim, evoluiu no sentido da descentralização econômica; houve mudanças significativas no relacionamento com o resto do mundo, promovendo-se a abertura para o intercâmbio comercial, científico-tecnológico e cultural (2000, p. 19).

O sistema jurídico também sofreu modificações, se é que se pode dar o nome de "sistema jurídico" ao que existia até então. Durante o período nacionalista pré-Mao, algumas normas haviam sido criadas, mas foram extintas sob a República Popular. De um modo geral, a China viveu numa sociedade onde as regras não eram claras e onde "a fonte da justiça era a autoridade moral do detentor do poder" (MEZZETTI, p. 124). A partir de 1980, códigos são criados e a associação dos advogados é reconstituída, o que serviu para trazer maior confiabilidade ao sistema como um todo, e para os investidores externos em particular.

Aspectos políticos, apesar de mais sensíveis, passaram pelo crivo das reformas. Deng insistia numa separação mais clara entre partido e Estado, na descentralização, no desenvolvimento do sistema legislativo, na transferência de muitas decisões para o nível local, além da já comentada substituição gradual dos quadros do partido, de um lado com a introdução de critérios meritórios e de competência para ingresso, de outro lado com o afastamento dos quadros mais antigos e vinculados a Mao Tsé-tung.

O tema da abertura política chinesa desperta discussões acaloradas. O mesmo personagem, Deng Xiaoping, que é considerado o “arquiteto” das reformas 
pelos chineses, foi aquele que ordenou a repressão da Praça da Paz Celestial em 1989. Após os acontecimentos de Tiananmen, Deng fez declarações elogiando os militares, o que demonstrou claramente sua responsabilidade nos acontecimentos, por um lado, ao mesmo tempo em que reforçou a idéia de que as aberturas promovidas seriam realizadas pelo partido, sem correspondente abertura democrática. Para entender, no entanto, o quanto as reformas econômicas continuavam indiscutivelmente em pauta, basta ler alguns de seus discursos:

Existe algo de equivocado na política de reformas e abertura? Não. Sem ela, teríamos o que temos hoje? Os resultados positivos desses anos devem ser avaliados corretamente ainda que tenham surgido problemas com a inflação. Se há algo errado, é que não fizemos suficientes reformas e suficiente abertura. Na fase de ajuste que devemos enfrentar, podemos dar maior ênfase à planificação, e em outro momento dar um papel mais amplo ao mercado. O importante é que a China nunca mais volte a ser um país fechado, que não subordinemos mais a economia a um controle rígido, como fizemos no passado (MEZZETTI, 2000, p. 436).

Sepultando de vez as ideologias e os métodos anteriores, defendendo as reformas e apelando para os estudantes após o episódio de Tiananmen, discorria ainda:

A pureza ideológica não faz crescer o arroz. Não importa que as reformas sejam de natureza socialista ou capitalista, o essencial é que façam com que as pessoas vivam melhor. Não são as reformas que põem em perigo a estabilidade, e sim o problema no interior do partido. Quem se opuser que saia da frente, não faça como aqueles que ocupam a privada sem defecar. Muitos anciãos permanecem aferrados a sua formação juvenil, não querem compreender o que é novo, não têm idéia do mundo de hoje. Criticam as zonas especiais mas recusam-se a vir visitá-las, para ver como as pessoas vivem bem. Querem que os quadros sejam sobretudo vermelhos, mas nós precisamos de técnicos, cientistas, estudiosos, administradores que saibam exercer sua missão, que conheçam o mundo moderno. Por isso é preciso estender as mãos aos estudantes que depois de junho de 1989 ficaram no 
exterior. É preciso fazê-los voltar, independentemente das posições políticas que tiverem assumido, não devem ter nada a temer, o país precisa deles, dos conhecimentos que adquiriram (MEZZETTI, p. 456).

Não é nossa pretensão compreender os acontecimentos de 1989 nem defender a repressão aos estudantes. A figura enigmática de Deng Xiaoping certamente mereceria estudos mais detalhados. Estava-se diante de um homem de idéias modernas, apesar de sua idade, que valorizava o conhecimento porque havia percebido que sem ele, nada poderia ser feito, mas de caráter duro, marcial, disposto a utilizar-se de meios violentos para não deixar que escapasse a oportunidade que tinha de transformar a China. O discurso anterior, que se nos permita a digressão nada científica, parece um apelo, um pedido de desculpas por um gesto que poderia, e em certa medida o fez, afastar aquela matéria prima crucial para a transformação chinesa: a inteligência e a criatividade do seu povo.

Uma pergunta que não quer calar, não obstante, é por que não aconteceram outras manifestações como aquela. Houve revoltas e ainda há revoltas na China, mas nenhuma de tamanha envergadura. Bergère (1990), ao analisar os eventos daqueles anos, chega a conclusões interessantes no sentido de que a mobilização tinha motivações em grande medida alheias a anseios por democracia.

Les manifestants étudiants qui s'adressent à leurs compatriotes et cherchent à les mobiliser s'en prennent avant tout à la corruption et à la rapide accumulation des richesses par ceux qui utilisent leurs fonctions officielles pour faire des bonnes affaires. Et les étudiants visent juste: les résidents urbains se préoccupent davantage de l'inflation et des maux qui l'accompagnent que de la démocratie. Le consensus entre les étudiants et la population s'établit sur une indignation partagée face à l'enrechissement des cadres corrompus. C’est pourquoi à mon sens l'équation: “propérité économique + blocage polítique $=$ mobilisation populaire” ne s'applique pas au movement contestataire de Tian’anmen (1990, p. 5).

O fato de não ter havido posteriormente outras de igual tamanho, ainda que o regime político tenha se mantido fechado, parece confirmar a hipótese 
segundo a qual os êxitos econômicos da China sustentam sua estabilidade social, o que, se por um lado se coaduna com a visão de Deng sobre a continuidade das reformas, coloca o PCC sob a ameaça constante de comoções internas, caso se falhe na consecução de tais políticas. O mais interessante, do nosso ponto de vista, é que os líderes chineses perceberam muito bem isso, o que os têm levado a se tornarem os mais eficientes possíveis no trato da administração, utilizando-se, sobretudo, como sua maior arma, do aperfeiçoamento de todo conhecimento técnico, científico e econômico que possa adquirir, internamente e no estrangeiro.

\subsection{Política Externa}

Falar em "política externa” na fase de transição de Deng Xiaoping nos remete a duas idéias: 1) a enunciação de uma lista de novos princípios e atitudes com relação ao mundo; 2) a percepção de que a linha divisória que separa a política externa da interna torna-se difícil de traçar, ainda mais quando um Estado decide inserir-se de forma tão intensa no mundo ${ }^{29}$. Esta última observação deve acompanhar nossas análises no último capítulo, posto que, como se observará, muitas das políticas “internas" chinesas têm conexões tão profundas com aspectos "externos" que a distinção entre as duas é por vezes incômoda.

O leque de novos princípios é grande. Não seria incorreto afirmar, contudo, que aquele que orienta ou dá sustentação aos demais é o de “abertura para o mundo exterior”. Em torno dele, outros se agrupam para especificar como se manifesta tal abertura: pragmatismo, multilateralismo, pacifismo, oposição à hegemonia (CHENG, 1985, p. 109), ênfase na economia, etc. Esta nova forma de atuar perante e dentro do sistema era o oposto da política externa de Mao e coadunava-se com as reformas internas que Deng pretendia realizar.

Passa-se de uma postura isolacionista, onde a China é "mal-vista" pelo resto do mundo, para uma postura de aproximação política com os mais variados países, de ingresso em organismos internacionais, de abandono da ideologia

$29 \quad$ Baylis diria: "The conceptual shift involves embracing the idea of global politics: the politics of an embryonic global society in which domestic and world politics, even if conceptualy distinct, are practically inseparable” (2008, p. 15). 
como critério de relacionamento externo, de participação nos fóruns e instituições internacionais, de abertura econômica aos investimentos e empréstimos estrangeiros e de tentativa de resolução de seus conflitos por meios pacíficos ${ }^{30}$. Nas palavras de Wang:

The ascension of Deng Xiaoping in 1979-1980 meant that Chinese foreign and domestic policy was no longer dictated by political ideology but instead by practicality . (...) As the Chinese economy rapidly expanded, it became more dependent on international trade and began to prioritize stable diplomatic relations in order to ensure economic growth (2007, p. 38).

Apesar de uma breve Guerra com o Vietnã ${ }^{31}$, na qual foi derrotada, os anos seguintes foram de amplas aproximações. Desenvolveram-se relações antes cortadas: Romênia e Iugoslávia; acordos comerciais foram realizados com a Comunidade Européia, com visitas à França, Alemanha, Inglaterra e Itália; efetuouse um diálogo com a Inglaterra para a volta de Hong Kong à soberania chinesa; a parceria com os EUA continuou, com a garantia dada sobre a não interferência militar em Taiwan em troca do reconhecimento de que a ilha pertencia à China; as relações com a União Soviética voltaram aos poucos à normalidade, sobretudo com a ascensão de Gorbatchev, enfim, as reformas internas e a nova postura da China aumentavam seu "capital de credibilidade” e desfaziam aos poucos as desconfianças (MEZZETTI, 2000, p. 359).

A “muralha” no interior da qual a China se mantivera isolada durante tanto tempo ruía a olhos vistos sob o influxo de uma nova visão quanto às relações internacionais. Aos poucos se desfazia a desconfiança quanto ao mundo exterior, assim como se agia para ser aceito por este. A China curava-se de suas feridas internas, incentivando seu povo a trabalhar e enriquecer e utilizando-se das conexões com o mundo para atingir a meta com maior rapidez. Pode-se dizer sem muito medo de errar que jamais na história chinesa uma abertura dessa monta foi realizada. Os

\footnotetext{
$30 \quad$ Em 1978 firmou a paz com o Japão, seu inimigo histórico.

31 Ironicamente, a derrota serviu também às idéias reformistas de Deng, pois demonstrava a ineficiência a que chegara um exército que não queria se modernizar.
} 
resultados dessa transformação foram espetaculares, mas sua descrição exaustiva não cabe num trabalho tão restrito.

Em 1988, uma série de televisão foi apresentada na China: a Elegia do Rio. O programa, por diversos motivos, fez enorme sucesso, inclusive por tentar traçar uma história da China que destruísse, entre outros, alguns dos seus fetiches. Sobre a famosa Muralha, há uma passagem trazida por Mezzetti (2000, p. 393) que vale a pena transcrever, para encerrar o capítulo:

Se pudesse falar, a Grande Muralha diria que nada mais é do que um imenso monumento à tragédia. Não representa nem força, nem progresso, nem glória. É um testemunho de fechamento, de autoconfinamento, de conservadorismo, impotente defesa e temor diante do estrangeiro. Por suas dimensões e sua venerável história, esse Nada deixou sua marca de autoengano no mais profundo de nossa consciência. Ah, Grande Muralha, devemos ainda cantar teus louvores? 


\section{O DRAGÃO LIBERTO: A CHINA ALÉM DOS MUROS}

Dando continuidade ao paradigma de "abertura" e "fechamento" que caracterizou a história chinesa, neste capítulo tentaremos demonstrar que a fase contemporânea das políticas interna e externa chinesa corresponde a um aprofundamento das políticas de Deng Xiaoping, configurando-se num momento de continuidade, e não de ruptura. Nesse sentido, analisaremos aspectos que nos parecem essenciais e que denotam a expansão e adaptação do legado do "arquiteto das reformas".

\subsection{Dados sobre a China contemporânea}

A China cresceu, durante os últimos vinte anos, numa média de 9,5\% ao ano $^{32}$. Dados sobre aspectos desse crescimento não faltam e são sempre impressionantes. Em 2008, talvez pela proximidade dos jogos olímpicos a serem realizados neste país asiático, várias revistas nacionais e internacionais trataram do tema “China”, com reportagens das mais diversas, com ênfase sobre seu crescimento impressionante ${ }^{33}$.

Segundo Fairbank (2008), suas receitas per capita quadruplicaram desde 1978. Em termos de comércio exterior, entre 2001 e 2004, a China foi responsável, de acordo com Arrighi, por um terço do aumento total do volume mundial de importações (2008, p. 216). Greenaway (2007) afirma que as importações cresceram a uma taxa anual de 17,9\% de 1990 a 2003, tendo as exportações crescido, no mesmo período, 19,7\%.

O país abriu-se aos investimentos estrangeiros e desde o início dos anos oitenta vem sofrendo o que Mezzetti denominou de "chuva de investimentos", tendo se tornado, no meio dos anos noventa, o segundo maior receptor de

\footnotetext{
32 O dado é de um estudo da OCDE de 2005, intitulado: Economic surveys, Volume 13. De acordo com ele, "Such an increase in output represents one of the most sustained and rapid economic transformations seen in the world economy in the past 50 years".

33 De memória, recordamos que a China foi capa da Veja, da Exame, da National Geographic, da Isto é, entre outras, sem contar que em todos os números da Foreign Affairs deste ano havia um ou mais artigos tratando de algum aspecto relacionado a China.
} 
investimentos diretos do mundo (WANG, 2002). Segundo Sun (2006), em 2003 a China teria ultrapassado os Estados Unidos como o maior receptor, sem contar que pôs em prática uma estratégia de investimentos no exterior que vem dando bons resultados também.

Em 1978 era a 32a economia do mundo, com um PIB de 1,8\% do total mundial, e com um comércio exterior de 20,6 bilhões de dólares. Hoje representa 6\% do PIB mundial, com um comércio de 2,17 trilhões de dólares ${ }^{34}$. Estes são só alguns dados sobre o crescimento chinês; não é difícil encontrar milhares de outros, mas aqui nos importa simplesmente constatar alguns resultados da abertura realizada por Deng.

A "política de enriquecimento" parece ter funcionado a contento. Os chineses seguiram a nova palavra de ordem e puseram-se a produzir, a vender, a comprar, a participar, e realizaram muitas das mudanças insufladas pelas idéias de Deng. O passado de miséria e de perseguição deu lugar à vontade de viver, de enriquecer, de se vestir diferentemente, de integrar a sociedade de consumo. Mezzetti relata como a simples chegada dos filmes ocidentais causou comoção entre os chineses no início dos anos oitenta (2000, p. 158). A transformação social que a abertura para o mundo ocasionou é um tema ainda não aprofundado, mas que merece sê-lo ${ }^{35}$.

\subsection{Continuidade ou ruptura?}

Como dito no início deste capítulo, a China contemporânea tem dado continuidade ao modelo inaugurado por Deng Xiaoping. Intentamos, portanto, demonstrar este fato analisando alguns dos aspectos mais atuais que denotam tal continuidade. Dividimo-los em aspectos econômicos, de política externa e de segurança, atentando para o fato de que tais categorias não são estanques, e que, ao contrário, se relacionam entre si. Ressaltamos também algo que fora colocado no

\footnotetext{
34 Os dados foram retirados de artigo publicado pelo Estado de São Paulo na internet: http://www.estadao.com.br . Acesso em 18 de dezembro de 2008.

Num capítulo da obra de Mezzetti intitulado “1980, entre o passado e o futuro”, o autor faz uma descrição emocionante e cheia de detalhes pitorescos sobre o que era a China dos anos oitenta. Comparando-a com o que é hoje, a mudança é indubitavelmente extraordinária.
} 
capítulo anterior, que a linha divisória entre o que é política externa e o que é política interna tornou-se confusa, sobretudo porque o sucesso econômico chinês deve-se, em grande medida, a conexões externas.

\subsection{Aspectos econômicos}

Esta categoria é, sem sombra de dúvidas, a que mais sofreu transformações. Muitas delas foram vistas no segundo capítulo. Trata-se agora de relacionar algumas "novas" mudanças que demonstram o aprofundamento das primeiras.

\subsubsection{Arranjos econômicos multilaterais}

A China tem participado de diferentes fóruns econômicos multilaterais ao longo do tempo, ou seja, não só proporcionou a abertura econômica como vem contribuindo com a construção de uma nova ordem econômica ao ingressar em instituições internacionais desta natureza. Evidentemente, isto não representa tão somente uma postura que tem repercussões econômicas, mas também políticas, ao dar claros sinais de que quer se inserir e participar das discussões como um ator "normal” e "responsável”. Wang (2000), tratando do envolvimento chinês em acordos de natureza regional, afirma:

China's involvement in regional economic groups has been a combination of nominal and qualitative multilateralism. Not only has the country become a member of multilateral groups, it has also expressed support of the major principles of multilateralism. The Chinese government has repeatedly stated that it advocates equality among members, open and free trade and investment, and nondiscriminatory treatment. This is a long way from the days when China viewed multilateral organizations as instruments of Western imperialism and refused to have any part of them (p. 481). 
Neste sentido, ingressou na APEC em 1990, na ASEAN em 1993, e tem sido um membro ativo do Fundo Monetário Internacional, da Organização Mundial do Comércio (SHUJA, 2007) e do Banco Mundial, tendo se tornado, segundo YAHUDA (1999) o maior e favorito cliente deste último.

A interdependência econômica, que é uma das características mais marcantes do mundo globalizado, de certa maneira impõe à China a aproximação e o ingresso nestas organizações. Caso não agisse desta forma, estaria vivendo a interdependência sem participar da elaboração das normas que a regulam. Sendo o pragmatismo a tônica de sua política externa e ante a necessidade de dar continuação a seu desenvolvimento econômico interno, o processo de abertura exige da China um processo correlato de participação crescente.

Esta participação, ademais, se realiza em dois âmbitos: mundial e regional, com a atuação em organismos nas duas esferas. Com base nisso, a China tem acentuado o discurso do multilateralismo e criticado as soluções unilaterais, em boa medida para atenuar a visão que recai sobre ela de ser uma potência em ascensão que poderia resolver seus problemas por meios menos democráticos.

Embora Deng tenha aberto a economia e propiciado contatos com o mundo exterior, parece que a participação em fóruns e instituições internacionais tem se intensificado mais após sua saída, o que reflete um aprofundamento dos vínculos econômicos com o mundo.

\subsubsection{Investimentos externos}

A China não só se tornou um grande receptor de investimentos externos $^{36}$ como as empresas chinesas foram incentivadas a investir no exterior. $\mathrm{O}$ papel do Estado, nesse caso, foi essencial, tanto ao incentivar as empresas quanto ao participar diretamente, por meio das estatais (WANG, 2002). Alguns dos principais países-alvos desses investimentos são a Austrália, o Canadá e os Estados Unidos. A partir dos anos noventa, o país tem diversificado bastante estes destinos, dando-se

\footnotetext{
36 Embora no início da abertura, a indústria fosse mais simples, avanços significativos na área tecnológica ocorreram. Agarwal (2004) afirma: “This high level of FDI flows has transformed China into the world's major center of manufacturing, not only in labor-intensive industries such as footwear, clothing and textiles, but also in technology-intensive industries such as eletronics, computers, and telecommunication equipment” (p. 280).
} 
grande prioridade a países em desenvolvimento da Ásia, América do Sul e África (WANG, 2002, p. 197).

Confirmando a ligação entre problemas internos e objetivos externos, Wang afirma que uma das causas para esse "salto para fora” foi que a capacidade industrial chinesa, após duas décadas de industrialização, excedeu a demanda interna por esses produtos. Entre outras causas, cita ainda a necessidade de assegurar recursos externos, mercados em outras partes do mundo e, em muitos casos, evitar as tarifas de importação, já que produzindo no interior do país, não há a incidência destas (2002, pp. 200-202). O mesmo autor faz o seguinte resumo:

After over twenty years of a partially open door, China has not only become an important host of FDI, but also a significant source of FDI. Chinese government-initiated FDI is a complex venture. (...) China's industrial investments overseas have been motivated not only by traditional determinants - such as resource-seeking, market-seeking and efficiencyseeking - but also by the pressures of globalization and regionalization (p. 205).

A estratégia visa não somente benefícios econômicos: por vezes, tais investimentos são utilizados tendo em vista objetivos políticos, numa simbiose que torna impossível separá-los para efeitos explanatórios. Política e economia andam de mãos dadas na realização dos objetivos de inserção chinesa. No entanto, Sun (2006) aponta para uma mudança essencial ocorrida recentemente: o direcionamento político teria dado cada vez mais lugar à liberdade da iniciativa privada na escolha de como, onde e quando investir no exterior (p. 619).

Um dos pontos mais interessantes do crescimento dessas empresas, de sua expansão e de sua melhora qualitativa é o uso intensivo do instrumento das joint ventures. A política de abertura nunca foi realizada sob o influxo absolutamente livre das forças estrangeiras. Visando adquirir os conhecimentos tecnológicos externos, essa experiência demonstrou que é possível recuperar o atraso tecnológico. A China provou isto tanto com as empresas que se instalaram em seu território, quanto com a atuação de suas empresas no exterior. Segundo Sun (2006): 
(...) The method used by Chinese companies to overcome their technological disadvantages deserves more attention. It demonstrates that it is possible for companies from developing countries to overcome technological disadvantages by setting up R\&D centres in developed countries, and by acquisition, joint venture and development of strategic alliances with Western companies for technological development (p. 633).

Este aspecto é importante para se compreender o papel da “mão visível” (WANG, 2002) do Estado nas transformações econômicas por que passou a China. Mais uma vez, o conhecimento como meta permitiu a apropriação de tecnologias estrangeiras, sendo a abertura condicionada por regras que visaram esta apropriação. Muitos criticam tal política por considerarem que se trata de "roubo de idéias”, ou de imitação pura e simples, o que ocasiona impactos sobre a qualidade de muitos produtos “chineses”. De fato, a crítica procede, ao menos em parte, embora demonstre também o interesse dos países mais avançados em "congelar" as capacidades tecnológicas de terceiros.

\subsubsection{Ingresso na OMC}

As negociações para o ingresso da China na Organização Mundial do Comércio começaram em 1999, tendo sido concluídas em 2001, ano de sua aceitação na organização (LAI, 2001). O pedido de ingresso, no entanto, remonta ao ano de 1986. Segundo Arrighi, o país “concordou com um dos programas mais rápidos de corte de tarifas de importação e de abertura de mercado já aceito pelos novos membros” (p. 285).

O ingresso na OMC foi extremamente importante para a China. Mais uma vez confirma a hipótese de uma nação “normal”, responsável, que visa inserir-se no mundo por meio das instituições internacionais, participando de seus processos decisórios. A entrada proporciona maior credibilidade e, ao mesmo tempo, reduz as desconfianças contra a China, anulando também, ao menos em teoria, os argumentos que antes serviam para discriminar produtos chineses. 
Stable external, as well as internal, economic conditions are among the most important factors that influence medium and long-term developments. Externally, open markets for China's exports and high influx of FDI are crucially important: that is precisely why China joined the WTO in December 2001 (DECKERS, 2004).

As atitudes chinesas, tanto de agressividade comercial, quanto de proteção a alguns setores de sua economia, foram utilizadas das mais diversas formas para discriminá-la comercialmente; a partir de seu ingresso na OMC, teve que se adaptar às formas de luta dentro da organização, com especialização dos seus quadros diplomáticos e demais especialistas da área comercial (KENNEDY, 2005).

Lai (2001) aponta diversas causas externas para o ingresso na OMC, entre as quais podemos citar: eliminar as barreiras não-tarifárias contra seus produtos, escapar das restrições anuais do Congresso Americano ao seu status de Nação Mais Favorecida, criar um ambiente de longo prazo favorável ao crescimento, diversificar seu comércio, aumentar sua competitividade, etc. Entre as causas internas, o mesmo autor acrescenta o estabelecimento de normas de uma economia de mercado, o estímulo à exportação e à atração de investimentos externos, a geração de empregos e crescimento, o incentivo para setores anticompetitivos se adaptarem, o crescimento do padrão de vida da população, uma maneira de diminuir as pressões por reformas políticas e de aumentar os laços com Taiwan, facilitando assim a reunificação (p.250).

O mais importante, no nosso entendimento, continua sendo a mudança estrutural que dá ensejo a tudo isto, qual seja, a transformação de uma mentalidade chinesa milenar de aversão ao comércio. O resto são conseqüências desta modificação profunda, são acontecimentos superficiais que denotam a revolução em termos mentais, psicológicos e sociais. Em termos de continuidade, no entanto, são claramente aperfeiçoamentos da era da transição de Deng.

\subsubsection{Acordos de livre comércio}

Um dos aspectos mais recentes da política externa chinesa é a realização de acordos de livre comércio (YANG, 2007). Esta relativamente nova 
orientação decorreu da percepção de que as deliberações comerciais mundiais são por vezes muito lentas. Além do mais, os processos de regionalização vigentes no cenário internacional convenceram a China de que seu entorno revestia-se de suma importância para a sua expansão econômica. Segundo Yang:

China has become more vigorous in its pursuit of free trade agreements. It has been talking with 27 countries and regions regarding the establishment of nine FTAs, covering one-fourth of China's total trade. China's FTA partners include Chile (completed), the ten-member ASEAN group (signed), the six-member Gulf Cooperation Council and the five-member South African Customs Union (Botswana, Lesotho, Namibia, South Africa and Swaziland), New Zealand, Australia, Iceland and Pakistan. China has also proposed FTAs with Japan, South Korea, members of Shanghai Cooperation Organization, and even with India. (2007, p. 328).

A estratégia de formular acordos bilaterais complementa sua inserção no nível multilateral no âmbito da OMC. É um modo de "correr por fora” enquanto as negociações em âmbito mundial se encontram emperradas. Mais uma prova de pragmatismo e dinamismo de sua política externa. Yang ressalta que os chineses iniciaram esta política realizando pequenos acordos, como o do Chile, para ganhar experiência, com vistas a realizações maiores no futuro. Tais acordos revestem-se também de caráter de segurança, ao se criarem maiores laços com vizinhos e outros Estados.

Todos os aspectos econômicos e comerciais apresentados representam um aprofundamento da abertura para o mundo exterior inaugurada por Deng Xiaoping. São postos em prática por uma diplomacia eficiente e dinâmica e por um governo que tem plena consciência do que está em jogo, caso fracassem. O sucesso econômico-comercial é fator de estabilidade interna.

It has been widely accepted in China that developing its economy offers the "ultimate solution” to all internal and external problems (YANG, 2007, p. 348). 
Mas os chineses também estão cientes da dependência externa com relação à China. Nas palavras de Chen (1992):

As long as Beijing focuses on economic reform and its policy of opening to the outside world, China will surely benefit from this competition. No major economic power can afford to lose China's big market with its great potential if they wish to gain a strong position in the competition (p. 239).

\subsection{Política Externa}

Embora o título desta seção seja "Política Externa”, ressalte-se que as ações comerciais referidas acima são empreendidas, também, por meio da política externa, apesar de os objetivos a alcançar serem muitas vezes de natureza interna voltamos à velha e defasada dicotomia. O que se quer elaborar a seguir, não obstante, é o aprofundamento em termos de visão da política externa como um todo e de seus princípios.

\subsubsection{Uma nova visão de mundo?}

O ingresso da China não se deu tão somente em instituições econômicas e comerciais, como relatado acima. O país tem participado ativamente dos mais diferentes tipos de regimes, o que confirma a visão multilateral de sua política externa. De acordo com Yahuda (1999):

Chinese government has agreed to join a number of different kinds of regimes with varying degrees of readiness to observe those rules that limit its freedom of action. These include arms control, trade, the environment, intellectual property rights and even human rights (p. 654).

Isto não significa que não persiga típicos interesses nacionais, mas a forma como passa a fazê-lo se dá em fóruns internacionais, sob as vistas de toda a 
sociedade internacional. Isto porque não só pretende deslegitimar políticas unilaterais de outros Estados, como intenta anular a suspeição que paira sobre sua ascensão.

De fato, o discurso de Deng Xiaoping era o de abertura para o mundo exterior e, ao mesmo tempo, o de nunca buscar hegemonia. À medida que as reformas obtiveram sucesso e que a China passou a ser vista como uma potência em ascensão, as desconfianças externas voltaram. A história demonstrou aos ocidentais que a ascensão de novas potências, ao abalar o equilíbrio de poder, podia provocar guerras. Deste modo, as novas lideranças chinesas adaptaram o discurso, pugnando por uma “ascensão pacífica” do país. No fundo, trata-se da mesma política de utilização de instrumentos multilaterais, de aversão a posturas hegemônicas, mas com o acréscimo de um elemento a mais: o pacifismo da conduta.

Outras características são apontadas por Chai (2003), como a mudança da postura sinocêntrica para alguma aceitação de práticas e idéias ocidentais e globalizantes. O ocidente, nesse sentido, não é mais visto com tantas desconfianças. Isto é mais do que uma postura de aquisição de conhecimentos do ocidente para prover ao seu próprio avanço tecnológico, como advogado por Deng nos primórdios da abertura. Trata-se, isto sim, de uma verdadeira aproximação que envolve atores sociais importantes, modificando comportamentos. O número de estudantes chineses que freqüentam universidades no exterior, por exemplo, sobretudo americanas, não pára de crescer.

A descentralização que atingiu esferas internas do governo também teve repercussões na política externa. Alguns autores argumentam que a certas províncias foram dadas liberdades para tratar de assuntos referentes a comércio exterior (QUANSHENG, 1992). Na academia, apesar de não haver liberdade absoluta, multiplicam-se os think tanks e demais centros de pesquisa que tratam de relações internacionais, enriquecendo o diálogo intelectual sobre o tema. Isto não significa, porém, que os debates acadêmicos tenham grande influência sobre os tomadores de decisão da área externa (NING, 2000).

Por outro lado, medidas vêm sendo tomadas para tornar a política exterior mais transparente, a exemplo da utilização da rede mundial de computadores, que hospeda sítios como o do Ministério das Relações Exteriores ${ }^{37}$,

37 http://www.fmprc.gov.cn . 
com informações sobre princípios que regem a atuação externa, discursos de autoridades, eventos internacionais, posições diplomáticas e outros.

Estas e outras medidas demonstram um enorme esforço por parte dos dirigentes chineses, não só para aprofundar a abertura de Deng, mas para torná-la aceitável externamente, para eliminar dela qualquer traço de agressividade que ao país possa ainda estar associada. Deng Xiaoping tinha uma visão sobre os benefícios que a abertura e a aproximação com o exterior trariam à China e seus seguidores puseram em andamento e aceleraram os planos para atingi-la. Não obstante, o que vemos hoje é uma inserção tão profunda, tão interdependente em seus efeitos, que a aceitação da China pelos seus pares não é mais uma escolha a ser feita, mas uma necessidade que impõe o discurso pacifista, conciliador e multilateral.

Terril (2005) aponta cinco objetivos do PCC que vale a penar transcrever: 1) estabilidade interna; 2) crescimento econômico; 3) manter um entorno estável e pacífico; 4) aumentar a reputação da economia chinesa após a crise asiática de 1997, que pouco a abalou; e 5) ser percebida como um “igual” pelos Estados Unidos. Os três primeiros objetivos estão intrinsecamente relacionados: é preciso manter o crescimento econômico, que é, em grande medida, a maior fonte de estabilidade interna e de legitimação do Partido Comunista. Para isto, é preciso que os negócios continuem, de modo que um entorno pacificado é pré-requisito essencial de continuação do projeto chinês. Destarte, o discurso pacifista deixa de ser “meramente discurso”, no sentido pejorativo da expressão.

By reviewing China’s foreign policy adjustment in recent years, people can see very clearly that the main purpose of its new approach in foreign affairs is to provide a long-term peaceful environment for China's modernization and a favorable condition for its reform and opening-up policy (CHEN, 1992).

Se antes “enriquecer” era a meta, atualmente manter o nível de renda para manter a estabilidade social tornou-se o objetivo de "vida ou morte" do PCC. Esta percepção tem levado as novas lideranças, inclusive, a tratarem com mais cuidado os “temas sociais”, bem à esquerda do pensamento mais liberal, como se verá ao final deste capítulo. 
Apesar do tom multilateral, a China pretende exercer uma política externa independente, autônoma, mas sem que essa autonomia signifique isolamento. Os tempos de dependência, dominação e humilhação estão revolutos: a retração maoísta foi, de alguma sorte, a resposta traumática àqueles acontecimentos. Mas a transição de Deng representou o início da reconciliação, tanto interna quanto externa. Hoje, a China quer mostrar-se amadurecida, capaz de dialogar e de resolver seus conflitos por meios pacíficos, mas sem pressões ou ingerências estrangeiras.

A China mantém relações com países desenvolvidos e com países em desenvolvimento. Em tempos mais recentes, tem enfatizado o relacionamento com os últimos, num típico diálogo Sul-Sul. Várias razões a levam a esta aproximação, sendo uma das mais importantes a quantidade de recursos que eles detém e que interessam aos chineses para a manutenção de seu crescimento.

The developing countries having more than $80 \%$ of the world's population are vast in area, rich in resources and abundant in varied products. With huge market potential and special features of their development models, they may support one another and draw on each other's strong points to achieve common development for mutual benefit. The increase of their overall economic strength in recent years has enhanced the possibility and opportunities for their cooperation. South-South cooperation boasts a broad prospect and gigantic potentiality and constitutes an important and indispensable component of bilateral and multilateral international cooperation. But the national conditions and economic development between the developing countries are not quite the same. They generally suffer from a weak foundation and inadequate development fund. This situation has brought about some difficulties for the further expansion of South-South cooperation. We are of the view that the developing countries should proceed from a strategic height, probe actively and intensively new channels and ways for cooperation, safeguard their common interests to the fullest possible extent and join hands in coping with challenges brought about by economic globalization.

The numerous developing countries should strengthen solidarity, closely cooperate in international affairs and coordinate with each other. They 
should take an active part in formulating the "rules of the game" in international economic field, propel the reform of the international economic, financial and trade systems and strive to win over the right to equal development. They should, on the basis of equality and mutual benefit, actively develop external economic and trade, scientific and technological and cultural cooperation to accelerate their own development. Only through uniting themselves, can the developing countries elevate their position in the South-North dialogue and preserve their own interests to the fullest possible extent in the process of globalization ${ }^{38}$.

Nosso principal objetivo neste trabalho não é o de esgotar os traços que caracterizam a política externa da China contemporânea. O que nos interessa é demonstrar o quanto as posições atuais são fruto, em primeiro lugar, da abertura promovida por Deng Xiaoping, e, em segundo lugar, pela interdependência gerada por estas reformas em nível planetário. Nesse sentido, a política externa chinesa hoje não se insere mais por convicção, mas antes por necessidade. Recuos sempre podem ser adotados, mas o retrocesso à China de Mao, à China fechada sobre si mesma parece algo impensável ou mesmo impossível.

\subsubsection{Conquistando a vizinhança}

Uma das estratégias básicas desta nova fase é a reaproximação com os vizinhos. Trata-se, de fato, de uma reaproximação, visto que durante séculos a China foi considerada o "irmão mais velho" dos países asiáticos do seu entorno imediato, conforme já comentamos acima. Sua influência no continente era enorme. A necessidade atual de manter um entorno estável, aliada à visão cada vez mais negativa que se tem da potência regional dominante (EUA), tem proporcionado o relativo sucesso destas estratégias. De acordo com Perlez, citado por Arrighi (2008):

A sensação é de que a China tenta ao máximo agradar, ajudar, acomodar-se aos vizinhos, enquanto os Estados Unidos são vistos como país cada vez mais envolvido com sua própria política externa, impondo à força ao mundo 
este programa [...] Agora, o sudeste da Ásia, cujos líderes viam os Estados Unidos tradicionalmente como âncora da segurança regional, falam sobre a necessidade de fortalecer o relacionamento com Pequim (p. 215).

Esta é também a opinião de Kurlantzick (2006), que afirma que a mudança de percepção ocorreu nos anos noventa. Atribui esta mudança a dois fatores basicamente: aos erros cometidos pelos Estados Unidos e pelo Japão e à utilização do soft power chinês, que define como a "habilidade de influenciar os países do sudeste asiático pela persuasão, ao invés da coerção” (p. 271). O soft power inclui diversas abordagens, tais como assinatura de acordos bilaterais de cooperação; apoio a organizações multilaterais de cooperação; apoio a países em desenvolvimento que são “deixados de lado” pelos Estados Unidos e Japão; propaganda sobre a ascensão pacífica; mudança dos diplomatas antigos, mais vinculados à ideologia, por novos diplomatas que falam inglês e línguas locais; a criação de um "Corpo de paz” chinês na região; promoção da cultura e língua chinesas; ajuda econômica, etc.

Esta aproximação tem gerado, além da influência cultural e política, uma crescente integração econômica com os países da Ásia (GREENAWAY, 2007). Inclusive, diga-se de passagem, com países como o Japão e Coréia do Sul (WANG, 2007) ${ }^{39}$. Se alguém duvida de que a China seja a "locomotiva econômica” do mundo, parece menos duvidoso que tenha se tornado a locomotiva da Ásia ${ }^{40}$.

China has also become the center of a virtuous regional trade cycle that benefits Asia’s developing countries. True, China sucks up vast quantities of raw materials, but for fifths of its imports are now manufactured goods, including office machines, telecom equipment, and electrical machinery. Neighboring countries are feeding the trade boom by exporting components and machines parts to China for final assembly. Korea and Taiwan have benefited the most, but the Philippines, Thailand, and Indonesia saw their annual exports to China shoot up by roughly 30 percent last year. Other regional production networks are developing, notably in automobiles and

$39 \quad$ Este autor afirma: “China recently became both Japan’s and South Korea’s primary trading partner” (p.39).

$40 \quad$ Segundo Oliveira (2008), “mais da metade do comércio externo chinês é feita com países da região. A China tornou-se, também, o maior recipiendiário dos IDE intra-regionais” (p. 13). 
garments, so the gains from this trade will probably endure even if one sector lags (KHARAS, 2005).

A aproximação com os vizinhos tem finalidades econômicas, geopolíticas e de segurança também. Na visão de Sheives (2006), além da segurança energética e de uma relação estável entre China e Estados Unidos, a estabilidade regional é o terceiro elemento da estratégia chinesa na Ásia central:

China's current foreign policy strategy is focused on assuaging fears of China threat, rather than on creating situations where states in the region feel threatened or dominated by a rising China (p. 206).

China's message to Central Asia continues to be: maintain regional stability at virtually any cost (p. 212).

Como se não bastasse uma política intencionalmente dirigida pelo Estado para “conquistar” a Ásia, o papel que os chamados “chineses de ultramar" têm desempenhado não é nada desprezível. A obra de Pinto (2000) é em grande parte dedicada ao estudo deste fenômeno. Em suma, há muito tempo chineses vêm se espalhando por toda Ásia, seja em busca de negócios, seja para melhorar de vida ou simplesmente para fugir às comoções internas. Mas uma vez no exterior, continuam mantendo contato com o centro. Estes contatos muitas vezes geram redes complexas de empreendimentos, e parcerias comerciais intensas, com regras próprias e relacionamentos baseados na confiança (RAUCH, 2002).

As táticas de aproximação da vizinhança reforçam o argumento da busca de estabilidade para a continuidade do desenvolvimento chinês. O interessante é notar como pouco a pouco a China tem ganho a admiração e a confiança destes vizinhos. É significativo que os textos acadêmicos que tratam da "ameaça chinesa” provenham, em sua maioria, dos escolares americanos, e não dos que compõem o ambiente próximo à China. Isto tende a indicar por um lado a perda da hegemonia americana na região e, por outro, o sucesso da China em aproveitar o vácuo de poder para instalar sua própria influência. Aspectos geopolíticos e geográficos, além da reconfiguração do poder mundial Pós-Guerra Fria, com um relativo declínio do 
poderio norte-americano, tendem a fazer pender a balança para o lado chinês, ao menos regionalmente.

\subsection{Segurança}

Este é um dos temas mais fascinantes da ascensão chinesa e tem gerado enormes debates, sobretudo no seio das correntes realistas das relações internacionais. A segurança será considerada aqui num sentido mais amplo, como exige a realidade contemporânea, que tornou o conceito mais complexo e multifacetado. Dividimos esta seção em duas, tratando na primeira de segurança militar, e na segunda de segurança energética.

\subsubsection{Segurança militar}

O maior debate sobre a ascensão da China tem claras conotações realistas. Indaga-se se ao prejudicar o antigo equilíbrio de poder mundial, o Estado chinês não estaria seguindo um caminho bem conhecido da Europa, qual seja, aquele que levaria à guerra. O discurso da diplomacia e dos líderes chineses, como já se viu, é o de uma "ascensão pacífica"41. As correntes realistas, no entanto, dando excessiva ênfase nos aspectos de segurança, acreditam que esta ascensão representa um perigo que precisa, de alguma forma, ser “contido”. Evidentemente, não se trata aqui de tentar prever o futuro: a China utilizará seu poderio militar moderno para fins políticos externos ou não? Ao analista de relações internacionais não cabe adivinhar o futuro, mas tão somente expor, na medida do possível, os argumentos sobre o tema.

Os realistas, sobretudo estudiosos norte-americanos, criticam a falta de transparência quanto ao orçamento militar chinês e alardeiam um suposto aumento dos gastos neste setor, o que significaria um risco de pretensões expansionistas. Ademais, alertam para o fato de que a ascensão de uma nova potência representaria, em tese, um risco para os outros Estados. Embora esta regra não seja absoluta, sustentam que este fato é potencialmente provocador de guerras, e

41 A teoria foi criada no ano de 2003. Em contrário, por entender que se trata de mera retórica, ver SHIH (2005). 
citam como exemplo análogo a ascensão da Alemanha (ZHAO, 2005) no contexto europeu do final do século XIX e ao longo do XX.

Sem querer responder à pergunta posta no primeiro parágrafo, porque impossível, após os estudos realizados para a elaboração deste trabalho, parece-nos que há mais elementos que indicam o contrário do que pensam os realistas. Trazer estes elementos à tona não significa, de maneira alguma, afirmar que a China não se utilizará de meios militares para a consecução de objetivos políticos: qualquer Estado corre o risco de fazê-lo. Parece-nos, todavia, que esta utilização não é algo que esteja nas “segundas intenções” da política externa chinesa.

Em primeiro lugar, a história chinesa é muito diferente da européia. O espírito expansionista europeu nunca existiu na Ásia. A influência chinesa sobre o continente, como já se disse, foi mais cultural que militar. Segundo Arrighi (2008):

[...] O sistema de Estados nacionais da Ásia destacou-se pela quase ausência de competição militar interna e expansão geográfica externa. Assim, com exceção das guerras de fronteira da China, [...] os Estados nacionais do sistema asiático-oriental, antes de sua incorporação subordinada ao sistema europeu, viveram em paz quase ininterruptamente não apenas durante cem anos, mas sim durante trezentos anos (p. 323).

Uma segunda característica desse sistema seria a ausência, segundo o mesmo autor, de necessidade de construção de impérios ultramarinos, o que pode ser confirmado, no caso chinês, pelas viagens do navegador Zheng He, já citado, que apesar da superioridade militar de suas esquadras, não saiu à conquista de Estados vizinhos. As razões para esse pacifismo não são objeto desse estudo: alguns defendem que a China, por sua superioridade tecnológica e geográfica, não precisava de mais territórios nem de produtos inferiores aos seus; outros argumentam que todas as religiões que influenciaram o povo e o Estado tinham preceitos pacifistas em seu corpo de doutrina e que nunca houve “classe militar” na China (HU, 2006).

$\mathrm{Hu}$ acrescenta ainda que as guerras chinesas foram sobretudo defensivas, e que os seus imperadores se preocupavam mais com a estabilização interna. Além do mais, eram extremamente custosas (2006, p. 266). É fato, não obstante, que a partir do século XIX, com as invasões ocidentais, depois com as 
guerras civis e de libertação, alguma ênfase foi dada ao aspecto militar. Nada mais natural: o país foi dividido naquele século. Posteriormente, no século XX, teve suas fronteiras ameaçadas por vários Estados e seu território invadido, com grandes perdas humanas e humilhações de toda sorte. Após a Segunda Guerra Mundial, foi cercada pela presença americana, com seu apoio ao Japão e à Coréia do Sul. Para completar, a partir dos anos sessenta, o cisma sino-soviético quase levou a China e a Rússia à guerra por questões de fronteira.

Quando se pergunta então por que a China investe em armamentos, é difícil não perceber o cinismo de molde ocidental em tal indagação. Rumsfeld fez indagações deste tipo numa conferência em Cingapura em 2005; eis a resposta de Arrighi (2008):

Considerando que os aviões e navios de guerra norte-americanos patrulham constantemente o litoral chinês; que os mísseis nucleares norte-americanos estão apontados para a China; que bases norte-americanas cercam a China por todos os lados; e que nos últimos dez anos os Estados Unidos entregaram armas cada vez mais potentes a Taiwan, tudo isso considerado, como observa Michael Klare, “esses comentários devem ter sido espantosos” (p. 290).

Outros episódios ilustram, no mínimo, a agressividade americana e sua postura nada amigável nesse campo: o bombardeio à embaixada da China na Sérvia, em 1999 e o episódio do avião espião que invadiu o espaço aéreo chinês em 2001. Alguns autores defendem que a postura americana frente a União Soviética no pós Segunda Guerra foi um dos motivos para a própria continuidade do clima de tensão da Guerra Fria: quando se observam as atitudes americanas para com a China, o argumento parece valer agora num cenário diverso.

Visto por esse ângulo, é compreensível a política de modernização do exército chinês inaugurada por Deng. É natural também que os números sobre o montante do dispêndio no setor militar não seja de conhecimento amplo e generalizado, por tratar-se de informações sensíveis. Diga-se de passagem: o poderio americano e o seu investimento na área militar continuam sendo muito superiores ao de qualquer país do mundo, da China inclusive. 
Alguns dos principais problemas de segurança chinês são Taiwan, os conflitos de fronteira com a Rússia, conflitos de posse de algumas ilhas no pacífico, a questão do Tibete, o relacionamento por vezes tenso com o Japão, alguns movimentos extremistas no seu território, entre outros. O importante é que os chineses têm negociado diplomaticamente os conflitos fronteiriços, e a criação, por outro lado, da Organização para Cooperação de Xangai é um instrumento de natureza multilateral que serve tanto à resolução destes conflitos, sobretudo com a Rússia, quanto como um fórum de debates para soluções contra o terrorismo e os movimentos independentistas que atuam nos territórios dos dois Estados.

Quanto a Taiwan, o governo chinês sempre deixou claro que se trata de um problema interno, mas se comprometeu a não resolvê-lo pela força. Taiwan é um dos típicos exemplos de como a integração econômica com a China impede a tomada de medidas drásticas, que afetariam negativamente esta integração ${ }^{42}$. A relação entre os dois é um verdadeiro vai-e-vem de aproximação e distanciamento (SHEN, 2004), intercalado por momentos de tensão. Em 2008, foi estabelecido um vôo comercial direto entre o continente e a ilha, num sinal de que o momento atual é antes de relaxamento.

O relacionamento com os Estados Unidos é por vezes tenso, porém cada vez mais estreito. Suas economias estão extremamente conectadas, o que torna difícil qualquer atrito de nível militar. Os americanos sabem disso (PAULSON, 2008) e muitos advogam uma aproximação política ainda maior entre os dois gigantes. Não obstante, as pressões de Washington tendem muitas vezes a desconsiderar que a China, apesar do seu discurso, não pretende deixar que os americanos ajam "passando por cima” de suas posições. Quando em 2007, a China destruiu um dos seus satélites com o lançamento de um míssil (SHUJA, 2007), deu um claro sinal de que estaria preparada para uma possível militarização do espaço, como a defendida pelo governo americano de tempos em tempos. O incidente comprova, não que a China contemporânea é militarista, mas que tem plena percepção do seu novo lugar no mundo e sabe falar a linguagem dos grandes.

A questão não é o quanto a China está preparada militarmente. Indubitavelmente está. Além de ser uma das potências nucleares, vem modernizando

\footnotetext{
42 O Japão encontra-se na mesma situação de estreitamento de laços econômicos.
} 
seu exército desde as reformas de Deng. Mas o espírito que perpassa tal modernização é o mesmo que perpassa todas as reformas chinesas. A China quer, antes de tudo, ser uma nação moderna, rica e poderosa, não porque pretenda se expandir pela Ásia, mas antes porque não quer ser mais objeto da expansão de terceiros. Se há uma expansão que os chineses já vêm efetuando, cada vez mais eficientemente, é a expansão econômica. Essa sim é a "ameaça chinesa”. Mas uma ameaça tão paradoxal em seus efeitos que gera a própria dependência de quem a realiza.

Nesse sentido, as questões de segurança foram trazidas também às mesas de negociação, nos moldes de resoluções pacíficas de controvérsias. Isto porque, mais uma vez, tudo que a China não quer é ser vista pelos outros como um poder agressivo: sua economia e, sobretudo, sua estabilidade interna, dependem deste perfil de política externa mais comunicativo, que dialoga em vez de ameaçar, que propõe soluções em vez de utilizar a força. Em que medida tal postura difere das idéias de Deng? Pensamos que só são diferentes porque agora não se trata mais de uma escolha: ou a China age como um poder “responsável”, ou põe em risco todo o sucesso que conquistou até agora. Os chineses sabem muito bem que as armas do século XXI são uma economia sólida, um crescimento sustentável, um empresariado competitivo, entre outros.

According to the economic interdependence theory, economic interdependency and free trade is a force for peace, with economic selfinterest a powerful disincentive for war, as the benefits of trade outweigh the costs of territorial expansion. Because the war brings more costs than gains, it has become rationally unthinkable. So it is fair to say that China will hesitate to initiate war for fear of the economic repercussions. Instead, Beijing, using pragmatism in its foreign policy, will try to play a more proactive role in the Asian-Pacific region (SHUJA, 2007). 


\subsubsection{Segurança Energética}

Um dos maiores desafios externos da China é o suprimento crescente de suas necessidades energéticas ${ }^{43}$. Um ritmo de crescimento como o chinês exige fontes de suprimento cada vez mais amplas, o que obriga sua diplomacia a ser ainda mais eficiente. Esta necessidade tem aproximado a China de alguns países considerados como "parias" pela sociedade internacional, como Irã e Sudão (SHUJA, 2007). Estes não são os únicos exemplos. Na aproximação com tais países, a China investe pesadamente em infra-estruturas, pontes, hidrelétricas, e outros, para ter o direito de explorar riquezas como carvão, aço e petróleo. Segundo seu pragmatismo, não impõe condições quanto ao perfil de tais governos, razão pela qual é muito bem recebida ${ }^{44}$, mas gera atritos diplomáticos com países ocidentais, e é acusada de apoiar tiranos.

O abastecimento em energia é tão premente e preocupa tanto os líderes chineses que alguns já chamam a estratégia global de suprimento de “a diplomacia da energia” (KREFT, 2006) ${ }^{45}$. Por vezes, tem gerado uma nova forma de mercantilismo extremamente criticado, onde a produção nesses países é obrigatoriamente vendida para a China (p. 66), além de criar “alianças energéticas estratégicas”. Esta situação é de difícil sustentação para a diplomacia chinesa e o que temos visto nos últimos tempos é um governo que tenta se equilibrar no seu papel de ator “responsável” e, ao mesmo tempo, necessita da ajuda de governos não muito bem vistos pela opinião pública internacional.

A África é o continente por excelência onde essa diplomacia é aplicada. Os chineses estão na África desde 1955 (YU, 1977), mas sua presença tem aumentado e as razões para ela mudaram bastante. Antes, a Guerra Fria era um dos fatores dessa presença, nas lutas de independência do continente que foram apoiadas pela China; hoje, trata-se de fazer negócios. Segundo Hanson (2008):

\footnotetext{
43 Dados levantados por Sheives (2006) indicam que é o segundo maior consumidor de energia do mundo.

44 Há sinais de que já não são tão bem recebidos assim: ver Michel (2008). Passam a ser vistos também como imperialistas.

45 Kleine (2008) a denominou de “China’s new dictatorship diplomacy”.
} 
Chinese interest in Africa extends beyond oil. China now ranks as the continent's second-highest trading partner, behind the United States, and ahead of France and Britain. From 2002 to 2003, trade between China and Africa doubled to \$ 18.5 billion; by 2007, it had reached \$ 73 billion. Much of the growth was due to increased Chinese imports of oil from Sudan and other African nations, but Chinese firms also import a significant amount of non oil commodities such as timber, copper, and diamonds. China recently began to import some African-manufactured value-added goods, such as processed foods and household consumer goods.

O número de chineses no continente é de 550 mil, contra $100 \mathrm{mil}$ franceses e 70 mil americanos (MICHEL, 2008) e os laços políticos também têm se fortalecido, tendo a China realizado em 2006 um grandioso encontro com as 48 nações africanas em Pequim, The China Africa Summit ou FOCAC (BELLO, 2007). Apesar de algumas contestações a essa "invasão" do continente, a China tem aproveitado o vácuo de poder americano e soviético depois do fim da Guerra Fria, numa atitude pragmática que se repete em outros domínios e espaços geográficos.

De um modo geral, esta busca por energia tem se direcionado a todos os recantos do planeta. Trata-se de um gigantesco desafio para a China manter seu ritmo de crescimento e para tal deve movimentar-se com rapidez pelo cenário mundial, de modo a garanti-lo. Este é mais um aspecto que reflete a dependência externa a que está vinculada e que é fruto de sua abertura para o mundo. Deng Xiaoping provavelmente ficaria orgulhoso dos resultados que sua política obteve. E certamente preocupado também.

\subsection{Desafios internos}

Nem tudo são flores na China. Tamanho sucesso econômico não atingiu de forma uniforme o povo chinês. Tal se deu sob o signo de grande desigualdade social, com grandes diferenças entre cidade e campo. Estas desigualdades geram inquietações e distúrbios internos, o que tem levado o governo a voltar seus olhos para tais problemas (ARRIGHI, 2008, p. 32). O crescimento 
também tem causado enormes danos de natureza ambiental (ECONOMY, 2008b), com poluição do ar, de rios, aumento de doenças ligadas ao aparelho respiratório e desertificação de imensas áreas, entre outros.

Na província de Xinjiang, o governo luta para conter movimentos terroristas. O Tibete também tem sido um cenário de conflito, com o acirramento das tensões em 2008, antes dos jogos olímpicos, realizados pela China. Além do mais, parece haver no seio do povo um grande sentimento nacionalista que por vezes vem à tona, como quando ocorreu, em 2005, a visita do primeiro ministro japonês, Junichiro Koizumi, ocasião em que milhares de manifestantes foram às ruas para mostrar sua indignação quanto às visitas que aquele fazia ao monumento dos heróis de guerra, que na memória dos chineses são também os criminosos de guerra das invasões dos anos 30. Demonstrações do gênero acendem temores quanto à possível utilização política das massas, que não é fenômeno raro na China.

Os anseios por democracia são outro problema. Este é um tema de difícil tratamento, em primeiro lugar porque não há informações quantitativas confiáveis quanto a extensão desse movimento no interior da China. Sabe-se que há revoltas e contestações. Com um mundo crescentemente interligado pela informação via internet, televisão, etc, torna-se difícil esconder as experiências de outros países, as idéias sobre abertura política e democracia. Apesar de as novas lideranças chinesas estarem cada vez mais capacitadas tecnicamente, apesar de sua maior compreensão dos problemas sociais (OLIVEIRA, 2008), apesar de algumas experiências de descentralização política (THORNTON, 2008), o regime parece se manter porque se assenta sobre um sucesso econômico que tem tirado milhões de pessoas da miséria. O que ocorreria caso os sucessos econômicos desaparecessem? O PCC luta para não ter que descobrir a resposta a essa pergunta.

A crise financeira de 2008 também tem levantado questionamentos quanto à resiliência do partido no poder. A China, no entanto, segundo alguns (ALTMAN, 2009), está em melhor condições do que qualquer outro país para enfrentá-la. Aliás, os Estados Unidos e a Europa certamente sairão dela com legitimidade e poder bastante abalados. A doutrina pregada por eles durante mais de cinqüenta anos parece ter demonstrado seus limites. A China, por todas as potencialidades inerentes à sua economia e por tudo o que foi dito neste trabalho, 
poderia estar bem colocada para exercer um papel preponderante nas relações internacionais daqui pra frente. Estaríamos vivendo o deslocamento de poder que certos autores advogam? Estaríamos adentrando o século asiático no qual um “modelo chinês” estaria em ascensão, como na visão de Wolf?

Se a ascensão da Ásia prosseguir como nas últimas décadas, ela dará fim a dois séculos de dominação global da Europa e, em seguida, a seu gigantesco braço norte-americano. O Japão foi apenas o precursor do futuro asiático. O país mostrou-se pequeno demais e voltado demais para si mesmo para transformar o mundo. O que vem atrás - a China, principalmente - não é nem uma coisa nem outra [...] A Europa foi o passado, os Estados Unidos são o presente e a Ásia dominada pela China será o futuro da economia global. Esse futuro parece fadado a se realizar. As grandes perguntas são quando e quão suavemente ele se dará (ARRIGHI, 2008).

Como dito anteriormente, não cabe ao analista fazer previsões ou concordar/discordar de previsões alheias. Não obstante, apesar dos desafios internos sobre-humanos a serem superados, a China parece estar bem posicionada para ocupar um lugar de destaque nas relações internacionais no século XXI. Seu povo demonstrou uma capacidade incrível de se reerguer da miséria para alcançar a riqueza tão ambicionada por Deng. Seja como for, esta nova China é fruto das visões deste líder, fielmente postas em prática por um povo incrivelmente apto a segui-las à risca. 


\section{CONCLUSÃO}

A “China de Mao” foi um dos períodos mais conturbados da história chinesa. Segundo nossa análise, correspondeu ao último momento de isolamento do país, com profundos distúrbios internos e completa aversão ao trato com o mundo. As políticas reformistas de Deng Xiaoping representaram um novo momento. Transitou-se, gradualmente, para a abertura e o contato com o exterior.

Esta transição foi efetuada, em grande medida, pelas lideranças moderadas do Partido Comunista Chinês, sob a inspiração das idéias daquele que ficou conhecido como o "arquiteto” da China contemporânea. De fato, a China atual é o resultado daquela transição. Por que tal mudança ocorreu? Por que os novos líderes escolheram um caminho tão oposto ao de Mao? Provavelmente, os chineses estavam cansados de tantos erros, que resultaram em catástrofes humanas inigualáveis.

Não obstante, os líderes chineses poderiam ter continuado as políticas de Mao. Havia elementos ainda influentes dentro do partido que advogavam a fidelidade ao pensamento do Grande Timoneiro. Mas por alguma razão, venceram os partidários de Deng. Este fato representou uma clara escolha de retorno à normalidade da China, de retomada de seu papel no mundo, algo que não ocorria há séculos. Era a destruição da mentalidade isolacionista, da postura desdenhosa de um suposto Império do Meio, inexpugnável porque superior, que nada tinha a aprender com o estrangeiro. Deng, um líder extremamente pragmático, escolheu conciliar a sabedoria chinesa, o dinamismo do povo chinês, com os conhecimentos que porventura a China não possuísse para alavancar seu crescimento, para tirar os chineses da miséria, num processo que é um misto de práticas capitalistas com regulação e direcionamento do Estado.

O mais interessante é que se tratava, à época, de uma verdadeira escolha entre dois modelos, um dos quais havia demonstrado ser um completo fracasso. A China que hoje surpreende a todos é o resultado do modelo escolhido por Deng e seus seguidores. Em termos econômicos, trata-se indiscutivelmente de um enorme sucesso. No entanto sua dinâmica de abertura gerou uma interdependência tão profunda com relação ao mundo exterior que esse mesmo modelo, de certa 
maneira, limita incrivelmente as opções de política externa chinesa. A China aproximou-se tanto da economia mundial que, num abraço, aliou-se a seu destino de forma dificilmente reversível.

Esta é a conclusão a que chegamos. Ao analisarmos os traços da nova política externa chinesa, resta clara a estratégia de agradar, de não causar temores, de não afrontar terceiros, de conciliar interesses, de utilizar-se do multilateralismo, de não buscar hegemonia. Isto em nenhuma hipótese significa fraqueza; mas significa limitação. A China não é agressiva, entre outras razões, porque não é do seu interesse. $\mathrm{O}$ aprofundamento de suas ligações com o mundo a obrigam a não abalar as estruturas desse mundo, que são as que lhe proporcionaram o sucesso econômico dos últimos vinte anos. Ressalte-se mais uma vez que esta conclusão não significa que a China não usará da força, por exemplo, para a resolução de conflitos. Mas esta “solução” tornou-se nitidamente inviável. De algum modo, hoje não há mais escolha entre isolamento ou integração. 


\section{BIBLIOGRAFIA}

AGARWAL, James. China's entry to WTO: global marketing issues, impact, and implications for China. International Marketing Review, v. 21, n. 3, pp. 279300, 2004.

AHLBRANDT, Stephanie.; SMALL, Andrew. China's new dictatorship diplomacy. Foreign Affairs, v. 87, n. 1, pp. 38-56, 2008.

ALTMAN, Roger. The great crash, 2008. Foreign Affairs, v. 88, n. 1, 2009, pp. 2-14.

ARRIGHI, Giovanni. Adam Smith em Pequim: origens e fundamentos do século XXI. São Paulo: Boitempo Editorial, 2008.

BACHMAN, David. Differing visions of China's Post-Mao economy. Asian Survey, v. 26, n. 3, pp. 292-321, 1986.

BAYLIS, John. The globalization of world politics. New York: Oxford, 2008.

BELLO, Walden. China Eyes Africa: The New Imperialism? Multinational Monitor, v. 28, n. 1, pp. 23-26, 2007.

BENNETT, Gordon. Economy, Polity, and reform in China. Comparative Politics, v. 18, n. 1, pp. 85-100, 1985.

BERGÈRE, Marie-Claire. Tian’anmen 1989. Vingtième siècle - Revue d'histoire, Paris, n. 27, pp. 3-14, 1990.

Structures du pouvoir et politiques de modernization dans la Chine du $20^{\circ}$ siècle. Vingtième siècle - Revue d'histoire, n. 38, pp. 3-12, 1993. 
BERGSTEN, Fred. A partnership of equals: how Washington should respond to China’s economic challenge. Foreign Affairs, v. 87, n. 4, pp. 57-69, 2008.

BROADMAN, Harry. China and India go to Africa. Foreign Affairs, v. 87, n. 2, pp. 95-109, 2008.

CHAI, Winberg. The Ideological Paradigm Shifts of China's World Views: From Marxism-Leninism-Maoism to the Pragmatism-Multilateralism of the DengJiang-Hu Era. Asian Affairs, v. 30, n. 3, pp. 163-175, 2003.

CHEN, Quimao. New Approaches in China's Foreign Policy: The Post-Cold War Era. Asian Survey, v. 33, n. 3, pp. 237-251, 1993.

CHENG, Joseph. Reform of the economic structure and "one country, two systems”. The Australian Journal of Chinese Affairs, n. 13, pp. 109-120, 1985.

COHEN, Paul. The Post-Mao reforms in historical perspective. The Journal of Asian Studies, v. 47, n. 3, pp. 518-540, 1988.

CONFÚCIO. Os Analectos. São Paulo: Martins Fontes, 2000.

DECKERS, Wolfgang. China, Globalisation and the World Trade Organisation. Journal of Contemporary Asia, v. 34, n. 1, pp. 102-119, 2004.

DITTMER, Lowell. China in 1980: modernization and its discontents. Asian Survey, v. 21, n. 1, pp. 31-50, 1981.

ECONOMY, Elisabeth.; SEGAL, Adam. China’s Olympic nightmare. Foreign Affairs, v. 87, n. 4, pp. 47-56, 2008a. 
. The great leap backward? The costs of China's environmental crisis. Foreign Affairs, v. 87, n. 5, pp. 39-59, 2008b.

FAIRBANK, John King.; GOLDMAN, Merle. China: uma nova história. $3^{\mathrm{a}}$ Ed. Porto Alegre: L\&PM Editores, 2008.

FRAVEL, Taylor. China's New Diplomacy. Foreign Affairs, New York, v. 82, n. 6, 2003.

GLATZ, Ferenc. Bio-Cultural and Political Diversity: considerations and questions about China's recent History. East European Quarterly, v. 40, n. 2, 2006.

GOODMAN, David. China: the transition to the post-revolutionary era. Third World Quarterly, v. 10, n. 1, pp. 111-128, 1988.

GREENAWAY, David. Has China displaced other Asian countries' exports? China Economic Review, v. 19, pp. 152-169, 2007.

HALPERN, Nina. China industrial economic reforms. Asian Survey, University of California Press, v. 25, n. 10, pp. 998-1012, 1985.

HANSON, Stephanie. China, Africa and Oil. Council on Foreign Relations. Disponível em: http://www.cfr.org/publication/9557/china_africa_and_oil.html?breadcrumb= $\underline{02 \mathrm{f}}>$.

HU, Shaohua. Revisiting Chinese Pacifism. Asian Affairs, v. 32, n. 4, pp. 256278, 2006.

IKENBERRY, John. The rise of China and the future of the West. Foreign Affairs, v. 87, n. 1, pp. 23-37, 2008. 
KENNEDY, Scott. China's Porous Protectionism: The Changing Political Economy of Trade Policy. Political Science Quarterly, v. 120, n. 3, pp. 407432, 2005.

KHARAS, Homi. Lifting All Boats. Foreign Policy. Disponível em: $<$ http://www.foreignpolicy.com/story/cms.php?story_id=2752\&print=1> Acesso em 16 out. 2008.

KIM, Samuel. Whither Post-Mao Chinese Global Policy? International Organization, v. 35, n. 3, pp. 433-465, 1981.

Thinking globally in Post-Mao China. Journal of peace research, v. 27, n. 2, pp. 191-209, 1990.

KREFT, Heinrich. China's Quest for Energy. Policy Review, n. 139, pp. 61-70, 2006.

KURLANTZICK, Joshua. China's Charm Offensive in Southeast Asia. Current History, v. 105, n. 692, pp. 270-276, 2006.

LANDES, David. A riqueza e a pobreza das nações. $11^{\text {a }}$ Ed. Rio de Janeiro: Elsevier, 2003.

LAY, Harry. Behind China's World Trade Organization Agreement with the USA. Third World Quarterly, v. 22, n. 2, pp. 237-255, 2001.

MACFARQUHAR, Roderick. Deng Xiaoping's reform program in the perspective of Chinese history. Bulletin of the American academy of arts and sciences, v. 40, n. 6, pp. 20-38, 1987. 
MAGNOLI, Demétrio. Relações internacionais: teoria e história. São Paulo: Saraiva, 2004.

MEZZETTI, Fernando. De Mao a Deng: a transformação da China. Brasília: Editora UnB, 2000.

MICHEL, Serge. When China met Africa. Foreign Policy, n. 166, pp. 39-46, 2008.

NG-QUINN, Michael. Deng Xiaoping's political reform and political order. Asian Survey, v. 22, n. 12, pp. 1187-1205, 1982.

- The Analytic Study of Chinese Foreign Policy. International Studies Quarterly, v. 27, n. 2, pp. 203-224, 1983.

NING, Lu. The dynamics of foreign-policy decision-making in China. Análise Social, v. 24, n. 153, 2000.

OKSENBERG, Michel. Economic policy-making in China: Summer 1981. The China Quarterly, n. 90, pp. 165-194, 1982.

OLIVEIRA, Amaury. A China e o fim da era anglo-saxã. Política Externa, v. 17, n. 1, pp. 7-21, 2008.

PAULSON, Henry. A strategic economic engagement: strengthening U.S-Chinese ties. Foreign Affairs, v. 87, n. 5, pp. 50-71, 2008.

PINTO, Paulo A. A China e o sudeste asiático. Porto Alegre: UFRGS, 2000.

POSNER, Eric. International Law and the Rise of China. Chicago Journal of International Law, v. 7, n. 1, pp. 1-15, 2006. 
QUANSHENG, Zhao. Domestic Factors of Chinese Foreign Policy: From Vertical to Horizontal Authoritarianism. Annals of the American Academy of Political and Social Science, v. 519, pp. 158-175, 1992.

RAUCH, James. Ethnic Chinese Networks in International Trade. The Review of Economics and Statistics, v. 84, n. 1, pp. 116-130, 2002.

SCHOENHALS, Michael. The 1978 Truth criterion controversy. The China Quarterly, n. 26, pp. 243-268, 1991.

SCHRAM, Stuart. Economics in command? Ideology and policy since the Third Plenum, 1978-84. The China Quarterly, n. 99, pp. 417-461, 1984.

SELECTED WORDS. Deng Xiaoping. Disponível em: $<$ http://english.people.com.cn/dengxp/>. Acesso em 16 out. 2008

SHEIVES, Kevin. China Turns West: Beijing's Contemporary Strategy Towards Central Asia. Pacific Affairs, v. 79, n. 2, pp. 205-224, 2006.

SHEN, Dingli. A diplomacia pragmática. Le Monde Diplomatique. Disponível em: < http://diplo.uol.com.br/2004-10,al1005 > Acesso em 02 de maio de 2008.

SHIH, Chih-Yu. Breeding a reluctant dragon: can China rise into partnership and away from antagonism? Review of International Studies, v. 31, pp. 755-774, 2005.

SHUJA, Sharif. Pragmatism in Chinese Foreign Policy. Contemporary Review, n. 289, pp. 62-69, 2007.

SUN, Laixiang. Dynamics of internationalization and outward: chinese corporations's strategies. The China Quarterly. London, pp. 610-634, 2006. 
TEIWES, Frederick C. Restoration and innovation. The Australian Journal of Chinese Affairs, n. 5, pp. 167-177, 1981.

. The paradoxical post-Mao transition: from obeying the leader to "normal politics”. The China Journal, Australian National University, n. 34, pp. 5594, 1995.

TERRIL, Ross. Inside Chinese mind. The Wilson Quarterly, v. 29, n. 4, pp. 4982, 2005.

THORNTON, John. Long time coming: the prospects for democracy in China. Foreign Affairs, v. 87, n. 1, pp. 2-22, 2008.

WANG, Hongying. Multilateralism in Chinese Foreign Policy: The Limits of Socialization. Asian Survey, v. 40, n. 3, pp. 475-491, 2000.

WANG, Lake. The good neighbor: why China cooperates. Harvard International Review, Cambridge, v. 29, n. 3, pp. 38-41, 2007.

WANG, Mark. The Motivations behind China's Government-Initiated Industrial Investments Overseas. Pacific Affairs, v. 75, n. 2, pp. 187-206, 2002.

WHITING, Allen. Chinese Nationalism and Foreign Policy after Deng. The China Quarterly, n. 142, pp. 295-316, 1995.

YAHUDA, Michael. Consolidation and problems of reform. The Australian Journal of Chinese affairs, n. 10, pp. 147-155, 1983.

. China's Foreign Relations: The Long March, Future Uncertain. The China Quarterly, n. 159, pp. 650-659, 1999. 
YANG, Jian. China's Cross-Regional FTA Initiatives: Towards Comprehensive National Power. Pacific Affairs, v. 80, n. 2, pp. 327-348, 2007.

YEE, Herbert. The Three World theory and post-Mao China's global strategy. International Affairs, v. 54, n. 2, pp. 239-249, 1983.

YU, George. China's Role in Africa. Annals of the American Academy of Political and Social Science, v. 432, pp. 96-109, 1977.

ZHAO, Suicheng. Nationalism Double Edge. The Wilson Quarterly, v. 29, n. 4, pp. 76-82, 2005.

ZHENG, Yongnian. Political incrementalism: political lessons from China's 20 years of reform. Third world quarterly, v. 20, n. 6, pp. 1157-1177, 1999. 